\title{
Methods Applied to the In Vitro Primary Toxicology Testing of Natural Products: State of the Art, Strengths, and Limits
}

Authors

Affiliations
Valérian Bunel ${ }^{1}$, Moustapha Ouedraogo ${ }^{2}$, Anh Tho Nguyen ${ }^{1}$, Caroline Stévigny ${ }^{1}$, Pierre Duez ${ }^{1,3}$

${ }^{1}$ Laboratory of Pharmacognosy, Bromatology and Human Nutrition, Department of Biopharmacy, Université Libre de Bruxelles (ULB), Brussels, Belgium

${ }^{2}$ Laboratory of Pharmacology and Toxicology, Health Sciences Faculty, University of Ouagadougou, Ouagadougou, Burkina Faso

${ }^{3}$ Laboratory of Therapeutical Chemistry and Pharmacognosy, Université de Mons (UMONS), Mons, Belgium

\author{
Key words \\ - biological assays \\ - cytotoxicity \\ - guidelines \\ - pitfalls \\ - natural products \\ - toxicity screening
}

received August 20, 2013 revised Dec. 10, 2013 accepted Dec. 11, 2013

Bibliography

DOI http://dx.doi.org/

10.1055/s-0033-1360273

Published online Jaunuary 15 , 2014

Planta Med 2014; 80 :

1210-1226 @ Georg Thieme Verlag KG Stuttgart · New York . ISSN 0032-0943

\section{Correspondence \\ Valérian Bunel}

Laboratory of Pharmacognosy,

Bromatology and Human

Nutrition

Department of Biopharmacy

Université Libre de Bruxelles

(ULB)

CP205/9 Bd. du Triomphe

1050 Brussels

Belgium

Phone: + 3226505250

Fax: + 3226505430

valerian.bunel@outlook.com

\section{Abstract}

$\nabla$

The present review attempts to build up a comprehensive picture of the major primary techniques used to screen and assess the cytotoxicity of plant complex mixtures. These can be based on metabolic activity, on membrane integrity, on morphological features, on cell growth; the type of cell death can also be established from more or less specific events (e.g., apoptosis, autophagy, DNA damage detection, reactive oxygen species involvement). This review will discuss the benefits, the difficulties, and the challenges that may occur along cytotoxicity testing of raw extracts and isolated natural compounds.

\section{Abbreviations \\ $\nabla$}

\section{7-AAD: 7-aminoactinomycin D}

AIF: apoptosis inducing factor

ATG6: autophagy-related gene 6

AO: acridine orange

BH3: $\quad$ Bcl2 homology domain 3

BrdU: bromodeoxyuridine

DAPI: 4',6-diamidino-2-phenylindole

DSB: double strand break

DTNB: 5,5'-dithiobis-(2-nitrobenzoic) acid

FISH: fluorescence in situ hybridization

GFP: green fluorescent protein

GSH: glutathione

GSSG: glutathione disulfide

rH2AX: serine139-phosphorylated histone H2AX

$\mathrm{H}_{2}$ DCFDA: 2',7'-dichlorodihydrofluorescein diacetate

HMGB-1: high-mobility group protein 1

INT: 2-(4-Iodophenyl)-3-(4-nitrophenyl)5-phenyl-2H-tetrazolium
LDH: lactate dehydrogenase

MDA: malondialdehyde

MMP: mitochondrial membrane permeability

MPTP: membrane permeability transition pore

MTS: 3-(4,5-dimethylthiazol-2-yl)-5-(3carboxymethoxyphenyl)-2-(4-sulfophenyl)-2H-tetrazolium

MTT: 3-(4,5-dimethylthiazol-2-yl)-2,5-diphenyltetrazolium bromide

OECD: organization for economic and co-operation development

PARP: poly-ADP-ribose polymerase

PI: $\quad$ propidium iodide

PI3K: $\quad$ phosphatidylinositide 3-kinase

PS: phosphatidylserine

PMS: $\quad$ phenazine methosulfate

QSAR: quantitative structure-activity relationship models

RNS: reactive nitrogen species

ROS: $\quad$ reactive oxygen species

TBA: thiobarbituric acid

TBARS: thiobarbituric acid reactive substances

TdT: terminal deoxynucleotidyl transferase

TNB: 5-thio-2-nitrobenzoic acid

TNF: tumor necrosis factor

TUNEL: terminal deoxynucleotidyl transferase dUTP nick end labeling

UDS: $\quad$ unscheduled DNA synthesis

WST-1: $\quad$ water soluble tetrazolium salt

XTT: $\quad$ sodium (2,3-bis-(2-methoxy-4-nitro5-sulfophenyl)-2H-tetrazolium-5-carboxanilide)

$\Delta \psi_{\mathrm{mt}}$ : mitochondrial transmembrane potential 


\section{Introduction}

\section{$\nabla$}

In vitro methods have become a cornerstone of drug discovery and are widely applied to the study of natural products, raw extracts, and isolated compounds, both for screening and mechanistic studies. Most products isolated so far have been tested on only a few of the myriad of cell and tissue models available and so, the field for research and discovery remains considerable. Whether researching cytotoxic, deleterious (toxic), or protective effects, the determination of concentrations that are cytotoxic to the model should be the primary step of in vitro testing.

Depending on the research scopes and on the further aims that are expected to be met, cytotoxicity may or may not be an endpoint on its own.

For instance, in studies trying to decipher the pharmacological activity of herbs that are traditionally used (i.e., for which no or low toxic effects are expected), toxicity towards in vitro cell cultures should be limited, notably in using proper doses or incubation times.

On the contrary, in works screening for potential anticancer compounds, cytotoxicity should be sought at the lowest possible concentration.

Plants have a long history of use for cancer treatment, although the efficacy of such traditional treatments should be cautiously evaluated. Indeed, cancer, a very specific and complex disease, seems to be poorly defined in the terms of folklore and traditional medicine [1] and certainly requires modern treatment modalities, based on surgery and radio- and/or chemotherapy.

Although cytotoxicity is neither necessary nor sufficient for anticancer activity, it is an activity consistent with antitumor activity as it is sensitive to every mechanism required for cell survival or cell death. The results of cytotoxicity screening, thus, could help to decide which materials are to be subjected to a fractionation/ purification process [2]. In that way, the phytochemical investigation of medicinal plants used for cancer treatment has undeniably resulted in the development of many important anticancer drugs, including paclitaxel, vinblastine, vincristine, rohitukine, etoposide, teniposide, or podophyllotoxin [3].

The present review attempts to build up a comprehensive picture of the major primary techniques used to screen and assess the cytotoxicity of herbal complex mixtures. These can be based on metabolic activity, on membrane integrity, on morphological features, on cell growth; the type of cell death can also be specified from more or less specific events (such as apoptosis, autophagy, DNA damage detection, reactive oxygen species involvement). The review will discuss the benefits, the difficulties, and the challenges that may occur along cytotoxicity testing of raw extracts and isolated compounds.

\section{Preliminary Considerations for Toxicity Screening of Natural Products \\ $\nabla$}

\section{Search for deleterious or protective activities}

For this type of research, the selection of concentrations to be tested in vitro represents a considerable challenge that is however frequently overlooked: (i) concentrations should reflect in vivo concentrations at the level of target organs, but these are most often unknown; (ii) concentrations depend on selected exposure times; (iii) stability in test conditions is often unknown; (iv) testing multiple concentrations may require considerable time and cost; and $(v)$ researchers eager to measure an effect may be tempted to use unreasonably high concentrations. Plasma or serum concentrations and pharmacokinetics of similar structure compounds may give a clue. These data are however frequently not available or may have been obtained on a surrogate animal species, sometimes at high dosages intended for a toxicological study. Such data may indeed entail particular metabolisms and toxicokinetics, irrelevant to physiological conditions in humans. For natural products, the situation may be less difficult as traditional use should be a guide to educated guesses [4].

\section{Basic requirements for (cyto)toxicity testing of herbal products and raw extracts}

Before undertaking any tests on raw extracts, the complexity of herbal material should be considered, including basic questions such as defining the most appropriate herb naming system (botanical, common, pharmaceutical name or herbal drug name), determining the botanical identity of the test material, selecting the relevant part of the herb for testing, considering confounding factors such as geographical origin, natural growing environment, genotype, harvesting time (year, season, time of day) and conditions, storage, processing and extraction $[5,6]$.

The characteristics and composition of test material should be evaluated, e.g., by spectroscopy and preliminary phytochemical screening. Indeed, many tests are based on absorbance, fluorescence, or luminescence measurements and so the UV-visible characteristics of tested extracts and compounds should be considered. Tests measuring interactions with proteins or receptors may be biased by the chemical reactivity of tested compounds (e. g., aldehydes), by precipitating agents (e.g., polyphenols), by denaturing agents (e.g., saponins) or even by contaminating bacterial lipopolysaccharides [7]. An indication of the spectroscopic properties and composition allows foreseeing relevant controls.

\section{Dissolution of tested extracts and compounds}

Both in primary toxicological evaluation and cellular pathway highlighting, a co-solvent is often added to the culture medium for helping in dissolution of tested extracts and compounds; DMSO has imposed itself as a valuable vehicle. However the absence of a complete understanding of the effects of DMSO can preclude the reaching of accurate conclusions due to its numerous artifacts [8]. DMSO is notably a hydrogen-bound disrupter, a cell-differentiating agent, a hydroxyl radical scavenger, an intercellular electrical uncoupler, and an intracellular low-density lipoprotein-derived cholesterol mobilizing agent [8].

At usual working concentrations (up to $0.5 \%$; $\approx 70 \mathrm{mM}$ ), DMSO may notably induce effects on cell cycle [9], on protein phosphorylation [10], on expression of genes coding for drug metabolizing enzymes such as CYP [11]. However, a permeation of cytoplasmic membrane, assessed by LDH release of Caco- 2 cells, only appears for DMSO concentration higher than 10\% [12].

Thus, effects of co-solvent applied to the system should be evaluated via suitable control conditions.

For any testing, the solubility of tested extracts or compounds should be assessed at the beginning and the end of the treatment, as solubility can change during the course of exposure in the test system [13]; a rapid microscopy observation allows eliminating such artifacts. For example, biased data were suspected for the flavonoid diosmin that was found to slowly recrystallize in culture medium, yielding microscopic crystals over $48 \mathrm{~h}$ incubation [14]. 
Table 1 Cell death: morphological and biochemical characteristics.

\begin{tabular}{|c|c|c|c|}
\hline $\begin{array}{l}\text { Cell death } \\
\text { mode }\end{array}$ & Morphological features & Biochemical features & References \\
\hline Necrosis & $\begin{array}{l}\text { - Cellular swelling } \\
\text { - Organelle swelling } \\
\text { - Moderate chromatin condensation } \\
\text { - Plasma membrane rupture } \\
\text { - Leakage of proteases and lysosomes }\end{array}$ & $\begin{array}{l}\text { - Activation of caspase proteases } \\
\text { - Lower ATP level } \\
\text { - ROS overgeneration } \\
\text { - Hyperactivation of PARP1 } \\
\text { - HMGB- } 1 \text { release } \\
\text { - Activation of TNFR } \\
\text { - RIP1 phosphorylation } \\
\text { - RIP ubiquitination }\end{array}$ & {$[15,17,19-22]$} \\
\hline Apoptosis & $\begin{array}{l}\text { - Cellular and nuclear compaction } \\
\text { - Loss of mitochondria membrane potential } \\
\text { - Plasma membrane blebbing } \\
\text { - Nuclear fragmentation }\end{array}$ & $\begin{aligned} & \text { - } \text { Activation of caspases } \\
& \text { - Activation or inhibition of } \mathrm{Bcl}-2 \text { family proteins (e.g., Bax, Bak } \\
& \text { Bid, BH3) } \\
& \text { - } \Delta \Psi_{\mathrm{m}} \text { disruption } \\
& \text { - PS exposure } \\
& \text { - } \\
& \text { ROS overgeneration }\end{aligned}$ & {$[16,19,22-25]$} \\
\hline Autophagy & $\begin{array}{l}\text { - Lack of chromatin condensation } \\
\text { - Accumulation of autophagic vacuoles }\end{array}$ & $\begin{array}{l}\text { - Beclin-1 dissociation from Bcl-2/XL } \\
\text { - Dependency on ATG gene products } \\
\text { - LC3-I to LC3-II conversion P62Lck degradation }\end{array}$ & {$[19,20,26]$} \\
\hline Paraptosis & $\begin{array}{l}\text { - Extensive cytoplasmic vacuolization } \\
\text { - Mitochondria swelling } \\
\text { - Without morphological change of apoptosis }\end{array}$ & $\begin{array}{l}\text { - Expression of ILGFR (insulin-like growth factor receptor) } \\
\text { - Independency of caspase inhibitors and Bcl-2 proteins } \\
\text { - Activation of mitogen-activated protein kinase family }\end{array}$ & {$[27-30]$} \\
\hline Pyroptosis & $\begin{array}{l}\text { - Cellular swelling } \\
\text { - Loss of plasma membrane integrity } \\
\text { - Release of cytoplasmic content }\end{array}$ & $\begin{array}{l}\text { - Caspase- } 1 \text { activation } \\
\text { - Caspase- } 7 \text { activation } \\
\text { - Secretion of IL- } 1 \beta \text { and IL-18 }\end{array}$ & {$[15,16,31]$} \\
\hline
\end{tabular}

\section{The Forms of Cell Death}

Cell death, as one of the phenomena of the cell life cycle, often corresponds to a genetic reprogramming of the cell that leads to a cascade of changes in biochemistry and morphology. Cytotoxic agents may disrupt the cell membrane, perturb cellular functions or activate one of the programmed cascades, e.g., via kinase inhibition or "cell death" receptors binding. Depending on the considered definition of "life", several attempts have initially been made to classify cell death subroutines based on morphological characteristics. The concepts of "necrosis", "apoptosis", and "autophagy" have then been evolved to determine cell death modalities, yielding a number of cytotoxic assays, generally based on the determination of total cell death occurring in a population of tumor cells. Looking deeper into the molecular pathways that regulate and execute cell death program, many biochemical assays and cytotoxicity end-points have been developed to monitor cell death-related phenomena and further classify the different forms of death [15-18]. Some of these techniques, discussed in the present review, have become major tools for the screening and cytotoxicity assessment of raw herbal extracts and pure isolated compounds, but also for bioguided fractionations.

The major cell death mechanisms, defined from morphological and biochemical criteria, are summarized in $\bullet$ Table 1 .

Necrosis is morphologically defined by a gain in cell volume (oncosis), swelling of organelles, plasma membrane rupture and subsequent loss of intracellular contents. Cells, in response to acute hypoxic or ischemic injury, such as myocardial infarction or stroke, or to supraphysiological conditions, e.g., mechanical force, heat, cold, or permeabilizing agents, usually undergo necrosis [19-21]. Necrosis can occur in a manner regulated by signal transduction pathways and catabolic mechanism, a cell death sometimes called "necroptosis" that has a prominent role in multiple physiological and pathological settings [15,21]. Several me- diators can be involved, including ROS, calcium ions, the kinase RIP1, PARP, which can deplete cellular ATP, HMGB-1, TNF, and calcium-activated non-caspase proteases (e.g., calpains and cathepsins) $[15,17,21,22]$. Necrosis allows entrance of the DNAbinding PI, yielding characteristic fluorescent cellular bodies [20]. Apoptosis is morphologically characterized by rounding-up of the cell, reduction of cellular volume, chromatin condensation, and nuclear fragmentation. During the early process of apoptosis, cells become smaller due to condensation of cytoplasm and shrinking of organelles. The following step consists in a very characteristic chromatin condensation (pyknosis), a nuclear fragmentation (karyorrhexis), and plasma blebbing which are maintained until the end of the apoptotic process [16,19,23]. Apoptosis can be induced via cell "death receptors" or Bcl 2-regulated mitochondria pathways. Once a member of the TNF family or a death ligand binds to cell-surface death receptors, caspases 8 and 3 will be activated, and cells will be triggered to apoptosis. Another way is to activate proteins of the proapoptotic Bcl-2 family (Bax, Bak, Bid), leading to increased MMP, cytochrome $c$ release, and triggering of caspase 9, leading cells to apoptosis. The lack of antiapoptotic protein $\mathrm{BH} 3$ also causes loss of mitochondria membrane potential, which leads cells to apoptosis $[19,24]$. The externalization of PS in apoptotic cells but not in necrotic cells is considered as a marker of apoptosis. Other proteins, including annexin I and calreticulin, can also be exposed on the cell surface during apoptotic cell clearance [22]. Apoptosis is characterized by a lag period between PS and PI positivity, while in necrosis both events coincide. The extensive generation of ROS has been found in both apoptotic and necrotic pathways [19,25].

Autophagy is a self-digesting mechanism in which the cellular contents are engulfed by a double membrane known as an autophagosome and delivered to lysosomes for degradation. Sustained autophagy activation leads to a high turnover rate of proteins and organelles that overcomes the cell capacities and leads 
to death via an apoptotic pathway; whether autophagy in dying cells is the cause of death or an attempt to prevent it remains a matter of debates. The morphological characteristics of macroautophagy include vacuolization, degradation of cytoplasm contents, and slight condensation of chromatin. Autophagy is triggered by the formation of a complex set of autophagic-related proteins such as PI3Ks and the product of ATG6 (also known as beclin-1). Other ATGs are also involved in the regulation of autophagy. The lipidation of microtubule-associated protein, LC3-I to LC3-II, can also trigger autophagy [19,20,26].

Other forms of cell death have been described: often apoptotic and/or necrotic features have been detected, and end-point techniques to distinguish some of these mechanisms are still heavily debated. These forms include: (i) paraptosis that presents a necrotic-like morphology; paraptosis does not fulfill the criteria for apoptosis but is considered to be a programmed cell death as it can be stopped by inhibitors of protein synthesis and transcription [27-30]; (ii) pyroptosis, first identified in macrophages triggered by bacteria, is now recognized a more general cell death subroutine that is neither a macrophage-specific process nor only a result from bacterial infection [5]; morphological features of pyroptosis are typical of necrosis, but the most distinctive biochemical feature is an induced proximity-mediated activation of caspase- 1 , leading to an unusual caspase- $1 \rightarrow$ caspase- 7 cascade [15,16,31]; (iii) mitotic catastrophe, cell death occurring during mitosis, considered an oncosuppressive mechanism rather than a cell death executioner mechanism; (iv) anoikis, an adherent cell-restricted lethal cascade that is ignited by detachment from the matrix; (v) entosis, an homotypic cell-to cell "cannibalism" provoked by the loss of extracellular matrix interaction; (vi) parthanatos, a caspase-independent regulated necrosis-type pathway depending on early PARP1 activation with NAD ${ }^{+}$and ATP depletion paralleled by AIF-mediated chromatinolysis; (vii) netosis, a death phenomenon restricted to granulocytic cells and dependent on components of the autophagic machinery; and (viii) cornification, a cell death subroutine restricted to keratinocytes and functionally linked to the generation of the stratum corneum of the epidermis [15].

\section{Assays of Cell Viability Based on Metabolic Activity Measurements \\ $\nabla$}

\section{Tetrazolium-based assays}

Tetrazolium-based assays are probably the most widely used tests to determine cellular viability. Tetrazolium salts act as redox sensors that can be reduced by metabolically active cells into formazan derivatives, which can in turn be dissolved for spectrophotometrical assessment.

Principle: In 1963, Slater et al. reported for the first time that tetrazolium salts were reduced by the mitochondrial respiratory chain [32]. In 1983, Mosmann came up with the idea that this property could be used to measure cellular proliferation and survival, and developed the MTT assay [33]. Since the 60s, assumption has been made that the MTT ring cleavage was ensured by complex II of the respiratory chain which is composed of succinate dehydrogenase. Later studies however demonstrated that most of the MTT reduction occurred at extramitochondrial sites, involving pyridine nucleotides NADH and NADPH [34].

Besides MTT, several other dyes such as XTT, MTS, or WST-1 may be used. These present the advantage of carrying a negative charge that allows them to remain soluble after reduction, avoid- ing the formazan solubilization step [35]. XTT and MTS are however less sensitive to metabolic reduction than MTT. The addition of PMS as an intermediate electron acceptor can solve the problem and restore reliable sensitivity [36]; the complex XTT/PMS is reported less stable than MTS/PMS and the latter seems preferable [37].

Potential pitfalls: Herbal extracts being complex mixtures, many compounds may be suspected of interacting with tetrazoliumbased assays. Of these, antioxidants may possess a reduction potential sufficient to react with tetrazolium salts, resulting in survival overestimation [38]. This was notably demonstrated for ascorbic acid, tocopherol [39], and polyphenols such as flavonoids or tannins $[40,41]$; the MTT assay has even been validated to quantify the antioxidant potential of herbal extracts [42].

In cell-based systems, it appears mandatory to carefully wash the cells to remove the maximum of potentially interfering phytochemicals before adding the tetrazolium dye. Brugisser et al. have shown that the flavonoid kaempferol could directly reduce MTT; its effects were limited when the incubation medium was discarded and cell cultures washed properly [39]. But washing operations obviously will not be efficient for strongly adsorbed or internalized compounds.

Tetrazolium tests may also be influenced by modulations in mitochondria amounts and activities. For example, the flavonoid genistein induces a G2/M cell cycle arrest followed by cell death in tumor cells. As a consequence, the higher volume of G2/Mblocked cells harbors higher amounts of mitochondria and thus higher reductive capacities. MTT assay underestimated the growth inhibitory potential, as compared to direct cell count [43]. Similarly, substances interfering with the content in $\mathrm{NAD}(\mathrm{P}) \mathrm{H}$ can lead to mistaken survival estimations. The pro-oxidant tert-butylhydroquinone enhanced cellular viability with XTT assay as compared to crystal violet assay [44], which was shown to be a consequence of an increased amount in NADPH-generating enzymes such as glucose-6-phosphate dehydrogenase.

\section{Resazurin (alamar blue) assay}

Principle: Although resazurin is commonly presented as a redox indicator, the principle of the assay is the same as that of tetrazolium-based assays. Resazurin is reduced into resorufin, which may then be assessed by spectrophotometry or fluorometry. Resazurin is often presented as having higher sensitivity towards metabolic activity, and is able to assess as low as 200 cells/well [45].

Potential pitfalls: As for tetrazolium-based assays, washing steps prior to viability assessment seem mandatory, not only because antioxidants may directly reduce resazurin, but also because test compounds may exhibit fluorescence by themselves. The problem however seems limited: a profiling study revealed that, although up to $2-5 \%$ of library compounds fluoresced in the blue spectral region (coumarin-like fluorescence: $\lambda_{\mathrm{ex}} \approx 350 \mathrm{~nm} ; \lambda_{\mathrm{em}}$ $\approx 440 \mathrm{~nm}$ ), only $0.004-0.01 \%$ were fluorescent with excitation at $\approx 560 \mathrm{~nm}$ and detection at $\approx 585 \mathrm{~nm}$ (resorufin-like fluorescence) [46].

Resazurin, being non-toxic to cells, has also been used in timecourse determinations of survival/proliferation $[47,48]$. However, in interfering with cellular redox potential (e.g., via NAD(P) $\mathrm{H}$ reaction), resazurin can trigger a burst of ROS production, resulting in mitochondrial respiration impairment with decreased proliferation rates; this was shown for HL-60 and Jurkat leukemia cells [49]. Moreover, working with medium supplemented in proteins (serum or bovine albumin) impacts on the absorbance 
and fluorescence properties of resorufin [50]. The effect of resazurin on the considered cell type and the effect of proteins on measured signals should then be carefully considered for such time-course evaluations. Moreover, in end-point experiments, the use of protein-free media should always be recommended for the survival estimation step.

\section{Neutral red assay}

Neutral red (3-amino-m-dimethylamino-2-methyl-phenazine) is incorporated by living cells only, where it accumulates in lysosomes [51]. After cellular lysis, it can be assessed spectrophotometrically, showing linear correlation with living cells number [52].

At physiological $\mathrm{pH}$, the dye's charge is null, allowing it to penetrate cell membranes by passive diffusion. While reaching the lysosomes where $\mathrm{pH}$ drops down, the dye acquires a cationic charge and remains trapped. The use of media buffered at physiological $\mathrm{pH}$, such as those suitable for cell culture, usually prevents modification in the $\mathrm{pH}$ gradient that can affect cellular sequestration of the dye. However, using higher concentrations or longer incubation times, as well as decreasing temperature or $\mathrm{pH}$, may lead to precipitation of neutral red which can directly affect cellular viability [53]. Moreover, interesting morphological assessments, such as the vacuolization occurring in cell death, can be performed under a phase contrast microscope [51].

\section{ATP content assay}

Principle: The level of ATP, an energy transporter present in metabolically active cells, can be assessed via a bioluminescence reaction based on the oxidation of luciferin by luciferase; ATP being cofactor for the enzyme, light is emitted proportionally to its concentration [54] and presumably to the number of cells $[55,56]$. Cellular ATP is measured by direct lysis of the cells with a suitable detergent. Because of its high sensitivity - the assay is capable of measuring as low as 10 cells per well [57] - and its ability to measure cellular proliferation, the assay tends to replace the ${ }^{3} \mathrm{H}$-thymidine uptake assay [55]. The ATP amount present in each cell depends on its generation and degradation balance: ATP quantity drops soon after cell death, when production stops and ATPases still consume the remaining stock. Accordingly, this results in a loss of luminescence which generally correlates with other redox sensitive assays [57]. However, a study using lung cancer cells reported discrepancies between MTT and ATP assays when measuring the growth inhibition potential of chemotherapeutic drugs [58].

Potential pitfalls: Luciferase has been originally isolated from the firefly Photinus pyralis. Nowadays, a variety of other related enzymes are commonly used but all have been associated with artifacts [59], mainly with luciferase inhibitors; this has notably been demonstrated for resveratrol [60] and several other compounds ranging from fatty acids to luciferin-like products [61]. A profiling study of a library of 70000 compounds identified at least $3 \%$ of them able to inhibit luciferase; but it seems this proportion was underestimated because of the inability of the test to detect weak inhibitors [46]. Test compounds may also quench the lowlevel light emitted by bioluminescence. Thus, as discussed earlier, proper washing steps of cell cultures should follow incubation to remove eventual interfering substances.

Other interfering compounds include direct inhibitors of the respiratory chain enzymes. This is notably the case of capsaicin, an inhibitor of mitochondrial complex I [62]; of gallic acid and pyro- gallol, inhibitors of complex II [63]; and of quercetin, inhibitor of the F1-F0 ATP-synthase [64].

On the contrary, a study focusing on potential discrepancies between bioassays revealed that cell cycle arrest could increase cellular volume and average mitochondrial content, yielding overestimations of cellular viability when using tetrazolium (MTS)- and ATP-based assays [65]. Although cell volume and mitochondria mass are normally strongly coupled [66], drug-induced uncoupling may impair results interpretation; e.g., leukemia cell lines presented enhanced mitochondrial proliferation and respiration during the very first stages of apoptosis upon treatment with chemotherapeutic agents such as doxorubicin or gemcitabine $[67,68]$.

\section{Assays of Cell Viability Based on Plasma Membrane Integrity \\ $\nabla$}

\section{Measurement of LDH release}

LDH, a cytoplasmic enzyme released in case of advanced cell membrane damages, is assessed in cell culture supernatants. As LDH converts lactate into pyruvate, using NAD+ as a cofactor, the production of NADH can be quantified by reduction of tetrazolium dyes such as INT or MTT into formazan products $[69,70]$. Any interference with the activity of the enzyme will lead to underestimations of cellular toxicity. For instance, LDH inhibitors such as chloroquine display reduced toxicity as compared to neutral red and ATP content assays [71]. Tannins, a class of polyphenols known for their direct interaction with proteins and enzymes, also result in $\mathrm{LDH}$ inhibition $[72,73]$, as shown for wattle tannins and tannic acid [74]. A similar effect was observed with p-aminophenol, resulting in survival overestimation compared to resazurin assay [75].

Molecules presenting amphiphilic characteristics are also likely to interfere with the LDH test readout; their detergent-like activity is prone to permeabilize cellular membranes to release LDH, yielding overestimation of their cytotoxicity. This has been demonstrated for saponins such as ginsenoside Rg2, glycyrrhizinic acid, or primulic acid 1, for example [76].

\section{Trypan blue exclusion}

Viability testing using trypan blue relies on its ability of being excluded from live cells, an energy-dependent process requiring ATP. Dead cells or cells undergoing necrosis present compromised membrane integrity, letting the dye penetrate the cytoplasm to stain it in blue. The amount of dead/dying cells can then be manually counted using a hemocytometer, or by means of digital imaging microscopy. Alternatively, trypan blue may be solubilized and the absorbance measured between 580 and $610 \mathrm{~nm}$ [77]. As trypan blue is a weak acid, its affinity is increased for basic proteins; nuclei uptake is generally higher due to the presence of histones, yielding marked blue intensity, whereas the cytoplasm remains faintly stained [77]. This method was compared with the LDH assay, yielding similar survival estimations [78]. The presence of extracellular proteins may influence the readout of the assay. As compared to LDH and fluorescein uptake assays, trypan blue staining revealed falsely higher cellular mortality in an amyloid- $\beta$ peptide cytotoxicity study [79]; this was interpreted as a consequence of amyloid- $\beta$ peptide aggregation onto cell membranes that facilitates the retention of trypan blue. 


\section{Fluorescence staining}

Fluorescent dyes that penetrate cells in case of membrane's integrity disruption, and generally bind to DNA and/or RNA, are indicative of dying or already dead cells. These dyes are suitable for a large range of applications such as microscopy imaging, flow cytometry or microplate fluorescence measurements. PI accounts among the most widely used of these fluorophores. Once fixed to DNA and/or RNA, it exhibits a fluorescence intensity of 20-30 fold higher than unbound form [80]. 7-AAD and Hoechst dyes are other DNA-binding fluorophores widely used for the detection of dead cells.

\section{Assays of Cell Viability Based on Cell Growth/ Proliferation \\ $\nabla$}

As seen previously, assays based on metabolic activity evaluation, such as the MTT assay, are at risk not to correlate to the number of living cells, but rather to the amount of mitochondria-containing living matter. It was demonstrated that G2/M-arrested cells, containing higher mitochondrial-masses, displayed higher MTT reduction ability which was not correlated to the cell number [43]. Assays of cell viability based on cell growth maintain their interest to investigate such cases.

\section{Direct cell counting}

Cells can be harvested and manually or automatically counted. The method was successfully applied to the assessment of growth rates of Vero and BSC-1 cells after treatment with silibinin [81]. This technique presents the advantage of requiring basic inexpensive laboratory equipment but can entail high variability and is generally tedious.

\section{Evaluation of cell cycle phases distribution}

The analysis of cell cycle is a single-cell assay relying on DNA quantification coupled to flow cytometry. The technique generally relies on the use of PI, although other DNA-staining fluorophores may be used. Cells must generally be fixed and permeabilized prior to experiment. Quiescent (G0) and G1 cells will have a single copy of DNA, whereas cells in G2 and mitosis phases will have twice the amount of DNA, displaying fluorescence intensities twice as bright. Since the cells in S phase are synthesizing DNA, they will display intensities between those 2 extremes [82]. Depending on the settings of the system, the proportions of polyploidic cells (DNA content $>\mathrm{G} 2$ ) and apoptotic/necrotic bodies (size and DNA content < G0/G1) can also be estimated. The first flow cytometric detection of apoptosis was based on this methodology; in staining hypodiploid (sub-G0) cells, Nicoletti et al. claimed to assess DNA fragmentation, a feature occurring during apoptosis and autophagy [83].

Because DNA quantification relies on fluorescence intensity measurement, it is important to carefully remove cell clumps before data interpretation, as 2 cells in G0/G1 phases will exhibit the same intensity as a single cell in G2/M phase [82].

The distribution in cell cycle phases can bring valuable information on the proliferative behavior of cells. Whereas the method cannot distinguish G0 (quiescent) from G1 (proliferative) cells, increased or decreased proportions in S and G2/M phases are indicative of proliferation modulation. Attention should however be paid to results correlated to cell cycle arrest, such as the G2/ $\mathrm{M}$ arrest observed for the flavonoid genistein [43], which should not be confused with an accelerated proliferation. Molecules that are able to block the cell cycle are actively sought as such a cytostatic effect could contribute to an anticancer activity.

\section{Assays based on DNA synthesis measurement}

The BrdU and ${ }^{3} \mathrm{H}$-thymidine uptake assays are based on their integration's rate in the DNA synthesized de novo during the $\mathrm{S}$ phase of the cell cycle, which is directly indicative of cellular proliferation. However, pitfalls including DNA repair, abortive cell cycle reentry, and gene duplication may be at risk of generating artifactual overestimations of cellular proliferation [84].

BrdU incorporation: BrdU is a synthetic nucleoside analogue that can be incorporated by live cells in place of thymidine [80], which makes this probe a valuable marker of cellular proliferation. Following partial denaturation of DNA, incorporated BrdU can be revealed via immunostaining, using anti-BrdU antibodies. An alternative consists in using fluorescently tagged BrdU: the incorporation of the probe can be detected and quantified by techniques including flow cytometry, microplate reader measurements, or (live) microscopy imaging.

${ }^{3} \mathrm{H}$-thymidine uptake: The quantification relies on the detection of radiolabeled thymidine by scintillation counting or autoradiography. If this technique yields similar results as other proliferation assays, it also has several drawbacks, including the handling and disposal of radioisotopes, raising concerns for human health environmental hazard, and the need for specialized equipment and facilities [48].

\section{Clonogenic assay}

The clonogenic cell survival assay was initially described for studying the effects of radiation on cells. Considered the "gold standard" in radiobiology, the assay is applied to examine the effects of chemotherapeutic agents with potential applications in the clinic. Before or after treatment, cells from a growing monolayer stock are suspended by trypsinization, and about 50 cells are seeded into a dish. Upon 1-3 weeks of incubation, each single cell divides several times and forms a colony. Colonies are fixed with glutaraldehyde, stained with crystal violet and the plating efficiency (the proportion of cells that grow to form a colony) is measured with the naked eye $[85,86]$. The clonogenic assay evaluates the reproductive integrity of cells, testing the ability of every cell in a population to undergo "unlimited" division to form a large colony or a clone [86]. All the cells that make up the colony are effectively the progeny of a single cell [85].

It should be noted that the clonogenic assay detects the loss of clonogenic potential from all possible causes, including apoptosis and necrosis, occurring over a much longer period (7-21 days) after treatment than the typical apoptotic/necrotic and growth inhibition assays ( 24 to $72 \mathrm{~h}$ ).

In trials with combinations of camptothecin, a specific inhibitor of DNA topoisomerase I, and radiation, the clonogenic assay measured similar (human melanoma cells) and substantially higher (human fibroblasts) cytotoxicities than apoptosis and necrosis assays. Discrepancies were ascribed to cells dying in the period after the completion of the apoptotic/necrotic assays or to a detrimental effect of the additional steps of trypsinizing and replating the cells for the clonogenic assay [87]. Suboptimal growth medium, errors in counting the number of cells initially plated, and the loss of cells by trypsinization and general handling effectively complicate the procedure [85]. 


\section{Assays of Cell Viability Based on Morphology Studies $\nabla$}

Cell size and shape

Observations in phase contrast microscopy can support conclusions drawn from other cytotoxicity tests. Cellular morphologies characteristic of death type may be observed. Necrotic cells can be easily detected in adherent cell monolayers from their cytoplasmic membrane swelling. On the contrary, blebs, that are typical of apoptotic processes, can hardly be seen on confluent monolayers as compared to cell suspensions. The use of annexin $\mathrm{V}$ staining combined with fluorescent microscopy may however help in identifying apoptotic cells [88]. In phase contrast microscopy, plasma membrane shrinkage can also be indicative of apoptosis [89].

The use of microscopy is however regarded as time-consuming, operator-dependent and tends to underestimate the amount of dead or dying cells, as early phases of death may not display marked morphological features [90].

\section{Videomicroscopy}

The growth of a population of cells can be evaluated using computer-assisted microcinematography (time-lapse videomicroscopy). The method requires specific equipment such as an observation chamber, with temperature and atmosphere control, and a phase contrast or fluorescence microscope equipped with a digital camera recording images at regular intervals (e.g., every $4 \mathrm{~min}$ ). The time-lapse sequence can then be assembled to form a movie.

A videomicroscopy system notably allows assessing the number and duration of cell divisions to reveal mechanistic information and differentiate cytostatic and cytotoxic activities. Examples obtained in the study of antiproliferative activities of natural products on glioblastoma cells indicate that the method can assess (i) a growth inhibition by increased duration of cell divisions (observed for ophiobolin A) [91]; and (ii) the triggering of unusual microtubule dynamics (observed for cembrenoids accumulated in tobacco upon infection with Rhodococcus fascians) [92].

The cellular motility, a parameter important to the metastatic process, can also be measured by video tracking of individual cells [93]. This method revealed that ophiobolin A is able to decrease glioblastoma cells migratory capacities [91].

\section{Scoring of cell detachment}

As discussed in previous sections, assays based on metabolic transformation or on enzyme leakage may lead to misinterpretation if test substances interact with enzymes; alternatively cells can maintain some enzymatic activity after death. Microscopic observation of adherent cells, however, can clarify such issues. In a comparative study employing HepG2 cells, falsely negative toxicity has been reported, that was related to a loss of cells adherence [45]. In fact, incubating MTT or resazurin in unwashed wells allowed detached cells to reduce both dyes, yielding overestimation of cell survival.

Although manual and tedious, the assessment of cell detachment by a scoring method can prove important to assess cellular phenomena; such a scoring has notably been successfully applied to study antifibrotic activities of Chinese herbal medicines [94].

\section{Assays to Evaluate the Types and Mechanisms of Cell Death}

$\nabla$

Apoptosis/necrosis differentiation: annexin V/PI binding The assay is based on the measurement of phosphatidylserine translocation from the inner to the outer side of the plasma membrane, a process occurring in the early steps of apoptosis [19]. Annexin V, a serum protein of unknown function strongly binds to phospholipids, such as PS, in a $\mathrm{Ca}^{2+}$-dependent mode. In 1995, Vermes et al. designed an assay in which FITC-labeled annexin V could detect PS externalization [95]. The assay was coupled with PI staining to allow detection of later phases of apoptosis and necrosis during which plasma membrane's integrity gets altered. These two markers, simultaneously detected by flow cytometry or by fluorescence microscopy [96], allow differentiating the early from late apoptotic stages and apoptosis from necrosis. As apoptosis is expected to last between 12 and 24 hours depending on the stimuli and cell type [88], annexin V/PI binding only provides information on a precise time-point, ignoring the total amount of cells that have already undergone apoptosis. The assay presents high robustness as PS exposure is apoptosis-specific. However, care should be taken when working with herbal substances containing saponins, which may induce membrane integrity disruption and let PI penetrate the cytoplasm [97].

\section{Caspase 3 activity detection}

Caspase 3, a member of the Cystein-ASPartic acid proteASE family, is a key executioner of apoptosis phases; it is synthesized as a proenzyme, which is cleaved and activated by both caspases 8 (extrinsic pathway) and 9 (intrinsic pathway) [19]. In turn, it cleaves caspases 6 and 7, which will pursue the apoptotic process. One of the most commonly used tests to highlight apoptosis signal - regardless of the pathway involved - is based on the enzymatic cleavage by caspase 3 of a synthetic peptide probed with an optically active dye. The release of probes such as $p$-nitroaniline or 7-amino-4-methylcoumarin allows colorimetric or fluorometric determination of the caspase 3 activity, respectively [98].

As discussed earlier, fluorometric determinations may be at risk of false interpretation when testing natural products, fluorescent [46] or absorbing, at the excitation or emission wavelengths of the fluorophore.

\section{Fluorescence staining for autophagy - AO}

AO is a membrane permeable dye which once bound to DNA, emits green fluorescence, whereas RNA binding emits red fluorescence. It therefore can be used for cell cycle analysis (in place of PI) and also for the detection of apoptotic and autophagocytic cells. Indeed, AO can also be used to stain acidic compartments such as lysosomes, where it emits a orange-red fluorescence [99].

\section{Mitochondrial transmembrane potential}

Mitochondria play a key role in the apoptotic pathway: opening of the MPTP triggers disruption of mitochondrial membrane integrity and the loss of the $\Delta \psi_{\mathrm{mt}}$. This results in the release of caspases activators such as AIF and cytochrome c [19]. Alternatively, the loss of transmembrane potential can also lead ATP synthase to reverse its activity and deplete the cell in ATP stocks [100]. Other factors that can cause the MPTP to open include massive $\mathrm{Ca}^{2+}$ influx and the presence of free radicals.

Numerous lipophilic cationic dyes, such as rhodamine 123, that accumulate in the mitochondrial matrix have been developed [80]. These can be detected and assessed in live cells by fluores- 
cence microscopy, flow cytometry, or microplate reader measurement.

Several natural products having an influence on the MPTP have been identified. For example, these include compounds able to block MPTP - thus blocking apoptotic/necrotic processes - such as tanshinone IIA, isolated from Salvia milthorrhiza Bunge [101]; or compounds such as wogonin, isolated from Scutellaria baicalensis Georgi, able to promote MPTP opening by cytoplasmic $\mathrm{Ca}^{2+}$ increase, and thus presented as good candidates for antitumor activity [102].

\section{Assays Based on the Assessment of DNA Damages $\nabla$}

Depending on the extent of DNA damage, especially doublestrand breaks, cells may trigger death programs. Detecting DNA damage at concentrations sensibly lower than $\mathrm{IC}_{50}$ allows investigating this possible cause of death.

\section{Comet assay}

The comet assay, also called single-cell gel electrophoresis assay, is a short-term genotoxicity test widely used for the quantification of (i) DNA strand breaks, crosslinks, and alkali-labile sites induced by a series of physical or chemical agents [14,103-106] and (ii) incomplete excision repair events in individual eukaryotic cells $[104,107]$. Individualized cells embedded in agarose are lysed and electrophoresed. Fluorescence microscopy coupled with PI staining allows visualizing denatured DNA fragments migrating out of the cell nucleus during electrophoresis. The image obtained is a "comet" with a distinct head consisting of intact DNA and a tail containing relaxed DNA loops or broken pieces of DNA [108]. The comets can be classified by visual examination [109] or measured from morphological parameters obtained by image analysis and integration of intensity profiles [110-112]. The comet assay is a well-established, highly sensitive, rapid, and simple genotoxicity test $[103,113,114]$; the conditions for carrying a correct comet assay [13] and data interpretation [115] have also been established. In the study of death causes, some drawbacks can be encountered: (i) indirect mechanisms related to cytotoxic concentrations (e.g., DNA fragmentation in apoptosis or necrosis) can lead to positive effects [116]; and (ii) a ROS-mediated phenomenon may result in spurious DNA oxidative damage revealed by this probably oversensitive assay.

\section{TUNEL assay}

The TUNEL assay allows the detection of DNA fragmentation as a consequence of internucleosomal cleavage of genomic DNA, typical of cells undergoing apoptosis $[117,118]$ by labeling the ends of the degrading DNA with the TdT. Identification of TdT-labeled degrading DNA in the nucleus of cells is not sufficient to distinguish apoptosis from necrosis as chromosomal DNA degradation also occurs in necrosis; therefore further studies are required [119]. False positive stainings in the TUNEL assay were reported to be caused by the release of endogenous endonucleases as a result of proteinase treatment; this could be abolished by pretreatment of tissue slides with diethyl pyrocarbonate [120].

\section{yH2AX assay}

The measurement of $\gamma \mathrm{H} 2 \mathrm{AX}$ provides a biomarker of DSBs and may identify potential genotoxic activity [121]. $\gamma \mathrm{H} 2 \mathrm{AX}$ is measured by a labeled monoclonal antibody and microscopy (determination of foci number) or flow cytometry $[122,123]$. The $\gamma \mathrm{H} 2 \mathrm{AX}$ assay, an early marker for DNA damage, was found capable of detecting strand breakage at levels 100 -fold below the detection limit of the alkaline comet assay [124]. One $\gamma \mathrm{H} 2 \mathrm{AX}$ focus is estimated equivalent to one DSB [125], at least when less than 100-150 DSBs are produced [126]. The assay is mechanisticallyunderpinned. Indeed, it is well-known that $\gamma \mathrm{H} 2 \mathrm{AX}$ facilitates the repair of clastogenic DNA DSBs and is an integral component in the DNA damage response machinery of mammalian cells [121]. Due to the high sensitivity of the assay, drawbacks similar to those of the comet assay are expected.

\section{Ames test}

The Ames test is an in vitro method for genotoxicity assessment. It is a bacterial reverse mutation assay performed with histidinedependent auxotrophic mutants of Salmonella typhimurium (strains TA97, TA98, TA100, TA102, TA1535, TA1537, etc.) or tryptophan-dependent auxotrophic mutants of Escherichia coli (WP2 isogenic strains uvr) [127]. In the presence of a mutagenic product, selective pressure, from a medium depleted in the essential amino acid, results in reverse mutations and the growth of colonies that are counted. Several different strains of Salmonella must be used because each strain individually assays for a particular type of mutagen [128-130].

The Ames test is a well-established, highly sensitive, rapid, and simple genotoxicity test. However, it does not detect every genotoxic insult. Some common compounds, including flavonoids, yield very positive Ames tests but, having not shown any indication of carcinogenicity in animal studies, are currently considered as non-carcinogens [131].

\section{Micronucleus test}

A micronucleus is an acentric chromosomal fragment or whole chromosome left behind during mitotic cellular division, appearing in the cytoplasm of interphase cells as small additional nucleus [132]. Micronuclei induction can result from agents that induce chromosomal breaks (clastogens) or agents that induce mainly chromosomal gain/loss (aneugens) [133,134]. An index of chromosome breakage and loss can be easily detected by fluorescent staining of DNA (e.g., using Hoechst, DAPI, or AO) and microscopy analysis. Clastogens and aneugens are discriminated by use of FISH analysis or by size-classification of micronuclei. OECD recognizes the test as one of the most successful and reliable for the identification of genotoxicity [135]. The test is sensitive and uncomplicated to perform and to assess [133] but difficult to upscale in a high-throughput format. Automated assays based on image analysis method to size-classify micronuclei in order to discriminate aneugens from clastogens were however recently developed [136].

\section{UDS assay}

The UDS assay measures chemical-induced DNA excision repair by detecting labeled thymidine $\left({ }^{3} \mathrm{H}-\mathrm{TdR}\right)$ incorporation. The induction of DNA repair mechanisms is presumed to have been preceded by DNA damage, indicating the DNA damaging ability of a chemical $[137,138]$. A core limitation of the UDS assay is its inability to indicate if a xenobiotic is mutagenic; indeed, it provides no information regarding the fidelity of DNA repair and it does not identify DNA lesions handled by mechanisms other than excision repair [137]. 
Assays to Evaluate the Involvement of Oxidative Stress in Cytotoxicity

$\nabla$

ROS [including superoxide radical $\left(\mathrm{O}_{2}{ }^{-}\right)$, hydroperoxyl radical $\left(\mathrm{HO}_{2}{ }^{\circ}\right)$, hydroxylradical ( $\left.\mathrm{HO}^{*}\right)$, peroxyl radical (ROO*) and alkoxyl radical (RO'), hydrogen peroxide $\left(\mathrm{H}_{2} \mathrm{O}_{2}\right)$, singlet oxygen $\left({ }^{1} \mathrm{O}_{2}\right)$, and hypochlorous acid $(\mathrm{HOCl})$ ] and RNS [including nitric oxide $\mathrm{NO}{ }^{*}$, nitrosonium cation $\left(\mathrm{NO}^{+}\right)$, nitroxyl anion $\left(\mathrm{NO}^{-}\right)$, or peroxynitrite $\left.\left(\mathrm{ONOO}^{-}\right)\right][40,41]$ play essential roles at different levels of homeostasis; they can however induce deleterious effects, generally consisting in DNA damages, oxidation of unsaturated fatty acids (lipid peroxidation), oxidation of proteins, and oxidative inactivation of enzyme co-factors [139].

\section{General pitfalls inherent to oxidative stress evaluation}

Because the generation of ROS/RNS can be the cause or the consequence of processes involved in cytotoxicity, their direct detection - or the detection of their effects - may give important clues at implicated mechanisms. An elevated oxidative stress is generally indicative of a cytotoxic background that can be countered by antioxidants such as green tea polyphenols [140], silymarin [141], or coumarins [142]. These would then be revealed as chemoprotective (anti-cytotoxic) by most of the cytotoxicity tests we review here. But the situation may be quite difficult to assess as some antioxidants can also act as pro-oxidants; this was notably demonstrated in vitro for ascorbic acid [143]. The phenolic compounds of apple, such as gallic acid or quercetin, were shown to induce the production of $\mathrm{H}_{2} \mathrm{O}_{2}$ upon incubation in culture medium; this was linked to an inhibition of HepG2 cells proliferation, suggesting that similar artifactual generation of oxidative stress could have led many studies to conclude falsely positive antiproliferative effects of flavonoids and phenolic compounds [144].

Moreover, several quinones can undergo redox cycling upon incubation with reducing agents such as $\mathrm{NAD}(\mathrm{P}) \mathrm{H}$ [145], resulting in the generation of reactive oxygen species, which can in turn (i) oxidize cysteine residues of proteins [146] and obviously interfere with enzyme-based assays; and (ii) oxidize and/or deplete reduced metabolites such as NADH or ATP, interfering with assays such as MTT or ATP content determination [147]. Thus, oxidative stress should be evaluated when working with quinonecontaining natural products.

\section{Probes for the detection of ROS and RNS}

The quantification of ROS/RNS is not an easy task as they usually have short lifetimes and several cellular mechanisms are involved in their capture. Most often, these reactive species are measured indirectly by detecting their pro-oxidant effects, either on probes or on cellular biomarkers.

A large variety of fluorescent probes are marketed for the determination of ROS and RNS amounts [148], some being more or less specific towards a single or several ROS/RNS. The $\mathrm{H}_{2}$ DCFDA, probably the most often used dye, penetrates cytoplasm where esterases cleave acetate moieties - preventing further externalization - and acquires fluorescence properties upon oxidation, which allows quantification by fluorometry or flow cytometry [149]. Nonetheless, it is estimated that oxidized dichlorofluorescein is prone to leak plasma membrane by passive diffusion, especially upon transmembrane potential impairment [150] as well as through the efflux pump MRP1 [151]. Passive leakage can be partially prevented by the use of carboxy-substituted
$\mathrm{H}_{2}$ DCFDA probes that are more efficiently retained in the cytoplasm [152].

\section{Measurement of reduced glutathione content}

GSH is a cysteine-containing tripeptide whose thiol moiety can react with oxidizing agents, forming GSSG. Once oxidized, GSSG can be reduced back to GSH by glutathione reductase, using NADPH as a cofactor [153]. Thus, assessing GSH content somewhat corresponds to evaluating the cellular redox potential; its decrease is generally correlated to oxidative stress and predictive of a cytotoxic action. Several approaches have been developed for GSH determination, among which an enzymatic recycling method allows rapid and high-throughput analysis [154]. This assay is based on the reduction of DTNB to TNB which is then determined by spectrophotometry. GSSG formed during the reaction is recycled by glutathione reductase and NADPH. Proper removal of test substances from sample prior to analysis will avoid the presence of redox interfering compounds or direct inhibition of glutathione reductase. This last effect was notably highlighted for ajoene, a compound derived from alliin, originating from garlic [155].

Other approaches include the use of monochlorobimane, a probe acquiring fluorescence upon reaction with low molecular weight thiols, such as glutathione, $\mathrm{N}$-acetylcysteine, mercaptopurine, or peptides, and determined by flow cytometry [156].

In an in vitro study using dermal fibroblasts, Kim et al. demonstrated that high cell densities led to improved ROS resistance by increasing the total antioxidant capacity of the cell culture [157]. The authors suggested that cell density should be considered as a critical point when studying oxidative stress.

\section{TBARS assay}

Lipid peroxidation is generally not considered as a cause of cellular death, but rather a late-stage event. The most popular test to assess lipid peroxidation is based on the reaction of MDA with TBA, employed for the first time by Patton and Kurtz in 1951 for the evaluation of milk fat oxidation [158]. The generated product can then be assessed colorimetrically or fluorometrically. However, thiobarbituric acid is not specific to MDA but reacts with all aldehyde end-products of lipid peroxidation, making the assay notoriously difficult to reproduce; the test has thus been renamed TBARS assay. Several non-aldehydic compounds can also react with TBA: these include ketones, ketosteroids, acids, esters, sugars, imides and amides, amino acids, oxidized proteins, pyridines, pyrimidines, and vitamins commonly found in herbal products [159]. MDA may also originate from other sources than lipid peroxidation; the reaction between MDA and TBA requires elevated temperature and low $\mathrm{pH}$, conditions which are prone to favor the generation and further degradation of lipid peroxides, or the formation of MDA-reactive organic compounds [160].

More specific assays of MDA should be favored, based on highperformance liquid chromatography with pre-column derivatization or with electrochemical detection [160].

\section{Other Approaches Applicable to in Vitro Primary Toxicology Testing \\ $\nabla$ \\ Cytoskeleton integrity}

The cytoskeleton plays an important role in many cellular processes including cell movement, cell development, and cell morphology. Microtubules, actin meshwork, and intermediate fila- 
ments have been identified as major targets in the development of drugs used for cancer treatment $[161,162]$; their study may complete the primary toxicity screening by yielding important clues on the mechanisms of cytotoxicity.

Interference with microtubules: Scintillation spectroscopy was the first technique used to detect microtubule inhibitors. After incubation with radiolabeled test products, intact cells or protein extracts are suspended in a scintillation fluid, and the bound radioactivity is measured. This method allowed identifying microtubules as a target for colchicine. This method, sensitive and simple, has been largely used to screen cytotoxic products [162,163]. The difficulties of working with radioactivity have been overcome with the now common use of immunofluorescence counter-staining of anti-tubulin antibodies. Growing cells on glass coverslips, the fluorescence can be evaluated by microscopy and digital imaging, which has a number of advantages. This very sensitive method, which does not involve any enzymatic reaction, can also be routinely applied to detect different types of cell death-related events at the same time due to the distinct absorption/emission spectra of co-staining procedures (c.f. Sections "Fluorescent staining" in "Assays of cell viability based on plasma membrane integrity" and "Fluorescence staining for autophagy acridine orange" in "Assays to evaluate the types and mechanisms of cell death") $[90,162]$. The discovery of microtubule-destabilizing Vinca alkaloids, vinblastine and vincristine, has helped to establish the link between microtubules and cell death; stabilization of microtubules is also an efficient cytotoxicity mechanism, as shown for epothilone or taxol [164].

Interference with the actin meshwork: The actin cytoskeleton governs cell motility and shape and undergoes continuous remodeling. Small changes in its turnover's dynamic may lead to dramatic cellular changes. Phalloidin, a toxin isolated from the mushroom Amanita phalloides, is able to bind F-actin and prevent its depolymerization. Fluorescently tagged phalloidin allows microscopic visualization of the actin cytoskeleton, after cells have been fixed and permeabilized [165]. Palytoxin and its analogues, such as ostreocin-D or ovatoxin-a, isolated from zoanthids, were identified by immunofluorescence as potent tumor promoter and cytotoxic agents, which lead to actin filament distortion and trigger cell death or apoptosis [161]. Cytochalasin D (amycotoxin alkaloid), latrunculin A (a macrocyclic alkaloid from marine sponges), and jasplakinolide (a macrocyclicpeptide from marine sponges) all modulate actin polymerization and indicate an anti-migratory potential possibly useful for metastasis forestalling [166].

\section{The use of reporter genes}

Reporter genes, based on cell transfection, allow for direct evaluation of gene transcription upon stimulation of dedicated receptors or pathways. The technique involves the insertion of a marker gene (reporter) next to a gene of interest (target) and presents a broad range of applications. Examples of reporters include GFP and luciferase. By highlighting changes in the expression of a target gene, it is possible to elucidate the mode of action of toxicants, or to screen for potential toxicity involving the targeted pathway [167]. Although luciferase has a short half-life, some natural compounds may be at risk of stabilizing the enzyme, leading to its accumulation and to increased bioluminescence [46]. On the contrary, test compounds may also act as direct inhibitors of the enzyme (as discussed earlier).

GFP, firstly isolated from the jellyfish Aequorea victori, presents maximum excitation at $395 \mathrm{~nm}$, and emission at $504 \mathrm{~nm}$ [168]. GFP-based reporter lines are numerous, and are not limited to cell culture systems, but can also apply to model organisms such as zebrafish or C. elegans, allowing direct visualization of expression patterns $[168,169]$. As previously described, GFP may be used to tag actin, allowing direct visualization of the actin cytoskeleton [165].

For both reporting systems, natural compounds may interfere mainly as fluorescence/luminescence quenchers.

\section{The toxicogenomics approach}

"Toxicogenomics" $[170,171]$ is based on the concept that the toxic effects of xenobiotics on biological systems are generally reflected at cellular level by their impact on the expression of genes (trancriptomics) and proteins (proteomics) and on the production of small metabolites (metabonomics) [170,172-175]. Such studies involve a high number of measurements per endpoint to acquire comprehensive, integrated understanding of biology and to simultaneously identify the different factors (e.g., genes, RNA, proteins, and metabolites) rather than each of those individually [176]; changes in transcriptomics, proteomics, and/ or metabonomics profiles may serve as early, sensitive indicators of a potential toxicity and are thought to precede toxic outcomes [173]. In particular, gene expression data (transcriptomics) are thought to be more sensitive than traditional toxicological endpoints [177]. This approach is quite promising for future comprehensive primary toxicity screening but still needs considerable work and validation. A recent review evaluated the use of "omics" technologies to assess genotoxicity, teratogenicity, and nephrotoxicity, with emphasis on the application to herbal products and mushrooms, and analyzed the advantages and limitations of each approach [178].

\section{Model organisms}

Quite recently, easy-to-handle model organisms have been implemented, providing higher degree of physiological relevance and mechanistic information without the complexity of the classical in vivo models.

Among these, the zebrafish (Danio rerio) is an efficient and promising tool for toxicity investigations. Females can spawn up to hundreds of eggs each week; the small size of embryos and larvae (1-5 mm, depending on developmental stage), along with their transparency, allow direct microscopy observation of organs [169]. More, the rapid development of the offspring permits accelerated teratogenicity and genotoxicity studies in multiwell plates [179]. Assessments can be performed by adding the test compounds/extracts to the surrounding water. As a consequence, the study of less polar compounds/extracts will be hampered by their poor hydrosolubility. Zebrafish can also be transfected with reporter genes. Blechinger et al. established a stable transgenic zebrafish line expressing eGFP coupled Hsp70 upon exposure to cadmium. The transgene model proved to be reproducible and to react in a dose-dependent manner [180].

Other model organisms include Caenorhabditis elegans, a $1 \mathrm{~mm}$ long nematode that can be inexpensively cultivated in Petri dishes seeded with bacteria as a source of food [181]. Each worm produces about 300 eggs and completes its reproductive life cycle in 3 days, allowing to grow large populations rapidly [181]. Many mutant strains are available, easy to grow and to maintain, allowing to probe various metabolic and toxicity pathways [182]. C. elegans has been used in applications such as the study of aging, oxidative stress, neurotoxicity, genotoxicity, and nematocid activity $[183,184]$. 


\section{In silico methods}

These predictive methods generally refer to a computational experiment, mathematical calculation, or scientific analysis of substances data through a computer-based analysis [185], including rule-based expert systems, QSAR and three-dimensional computational DNA-docking model to identify molecules capable of non-covalent DNA interaction [178]. The application of in silico methods to complex mixtures such as herbal extracts is by evidence limited to the detection of known phytochemical compounds bearing known or new structural alerts for toxicity activity; they could, however, help to elucidate which compounds are responsible for a proven effect [178].

\section{Discussion \\ $\nabla$}

In the past decades, during which the herbalism trend has been continuously growing, the safety of herbal products has become a major concern in ensuring public health. Many herbs and extracts that are not fully characterized for their constituents or their activities, even sometimes for their botanical status, are used. Although numerous laboratory studies investigate traditionally used herbs, these usually focus on phytochemistry and on deciphering the pharmacological aspects of bioactivity(ies). Meanwhile, the toxicological aspects, including eventual risks towards human health, are still too often neglected.

This review presents the most commonly used in vitro assays among the numerous tests that can be applied for primary toxicity screening. These basic assays yield invaluable information, important for further investigations. Indeed, from cytotoxicity curves, the concentrations for further testing can be deduced. For compounds intended as cytotoxic (e.g., anti-cancer agents), further mechanistic studies can be performed at concentrations up to $\mathrm{IC}_{50}$ to unravel the key events in cell killing. By contrast, when assessing compounds for deleterious events that would be indicative of long-term effects (i.e., genotoxicity, chronic toxicity), studies should be performed at concentrations in the range $\mathrm{IC}_{10}$ to $\mathrm{IC}_{30}$ [13]. Compounds assumed to be protective should be tested from the highest no effect concentration up to $\mathrm{IC}_{10}$; if a combination toxic agent/protective agent is investigated, the cytotoxicity of the combination should ideally be tested [13]. In all cases, traditional use is an additional important guidance to select relevant concentrations and exposure schemes.

Comprehensive guidelines have been recently published, regarding the cytotoxicity assays and the tests to unravel the death pathway induced [90]. Their application to the testing of natural compounds is advisable, taking into account the short-comings and possible artifacts that can be encountered in testing complex and multi-component mixtures, such as herbal extracts. The major sources of problems underlined in the present review should be considered, especially in high-throughput test systems that may overlook basic questions. As such, ensuring proper knowledge of their principle (summarized in 0 Table 2) appears as a pre-requisite.

As discussed in the present review, bioassays often present a risk of misinterpretation. Whatever the method used, the following general guidelines should be advocated in testing natural products for primary toxicity:

- Verify the consistency of tested material with medicinallyused material (e.g., through chromatographic or metabolomics profiling);
- Use at least 2 assays relying on separate principles of detection, i.e., that are methodologically unrelated, and check for any discrepancy;

- Where relevant, check for natural product-mediated enzyme inhibition (e.g., LDH assay);

- Where relevant, evaluate the redox potential of the tested product (e.g., MTT assay);

- Work with "relevant" concentrations, provided that, according to Paracelsus, only the dose makes the poison; justify the selected concentrations range; beware of excessive changes in pH or osmolality [13];

- Perform UV-visible and phytochemical characterization of the tested extract, as some classes of compounds are at risk of interfering with many biological assays;

- Evaluate the effect of any co-solvent applied to the test system (e.g., DMSO, methanol);

- Plan experiments that respect the statistical integrity of data; wells from a single multi-well plate are probably not statistically-independent;

- Assess solubility at the beginning and the end of the treatment, as solubility can change during the course of exposure in the test system;

- Carefully and exhaustively wash cell cultures before measurements so as to remove as much test substance as possible.

\section{Conclusion}

$\nabla$

Natural products often benefit from a long history of therapeutic use and are thus generally acknowledged, by the public but also by therapists, as non-toxic. This assumption has however seldom been verified, and safety issues are raised about the use of less documented herbs. In this regard, primary screenings involving validated in vitro systems can help in assessing potential toxicities by rapidly pinpointing herbs that may cause concerns. It should however be noted that there may be significant influence of pharmacokinetics, such as the rate or extent of absorption, distribution, and metabolism that may obscure the conclusions of in vitro tests. In the large majority of cases, there are no data available regarding metabolism and ADME for a given herbal medicine product. Herbal drugs are also highly complex mixtures of potentially active ingredients, including compounds that may interfere with in vitro assays. Consequently, only a careful interpretation of the results obtained in such researches, based on a thorough understanding of the principles and limitations of applied tests, will avoid misleading positive or negative conclusion on the toxicology of tested natural products.

\section{Acknowledgements \\ $\nabla$}

Valérian Bunel is a fellow of the Fonds de la Recherche Scientifique - FNRS (FRIA grant).

\section{Conflict of Interest \\ $\nabla$}

None declared. 
Table 2 Principles of major tests for toxicity assessment.

Test

\section{Assays based on metabolic activity}

Tetrazolium-based assays

Resazurin assay

Neutral red

ATP content

Assays based on plasma membrane integrity

$\mathrm{LDH}$ release

Trypan blue exclusion

Fluorescence stainings

Assays based on cell growth/proliferation

Cell counting

Cell cycle phases distribution

DNA synthesis measurements

Clonogenic assay

Assays based on morphological evaluations

Cell size and shape

Videomicroscopy

Scoring of cell detachment

Assays for the detection of cell death mechanism Annexin V/PI staining

Caspase 3 activity

Fluorescence staining for autophagy

Mitochondrial transmembrane potential

Assays based on the assessment of DNA damage Comet assay

TUNEL assay

$y \mathrm{H} 2 \mathrm{AX}$ assay

Ames test

Micronucleus detection

Unscheduled DNA synthesis

Assays for the measurement of oxidative stress Probes for ROS/RNS

Measurement of GSH

Thiobarbituric assay

\section{Principle of the assay}

Redox sensors (MTT, XTT, MTS or WSTs) reduced by cellular metabolites such as NAD(P)H into formazans. The proportion of living cells is evaluated by spectrophotometry of formazan's concentration.

As for tetrazolium dyes; fluorometric or spectrophotometric measurement of resorufin.

Neutral red penetrates living cells and remains trapped in lysosomes. The amount of trapped dye is proportional to the number of cells.

Enzymatic assays in which ATP is a cofactor for the oxidation of luciferin by luciferase.

LDH leaks from altered cytoplasmic membranes and is determined enzymatically by the conversion of NAD into $\mathrm{NADH}$, which in turn reduces a tetrazolium dye.

Trypan blue penetrates membranes of live cells freely and is readily pumped out. In dying cells, ATP stocks drop down, and externalization of trypan blue stops.

Dyes penetrate cells when membranes are altered and bind to DNA and/or RNA, which modifies their fluorescence properties.

Cell suspensions can be counted with the use of a hemocytometer. Adherent cells require trypsinization. Cells are permeabilized and stained with DNA markers (c. f. Fluorescence stainings). Depending on the dye, prior RNA degradation may be required. Cells fluorescence intensities are recorded and phases distribution are analyzed with the assumption that cells in $\mathrm{G} 2$ and $\mathrm{M}$ phases have twice the amount of DNA as compared to G0 and $\mathrm{G} 1$ phases. The $S$ phase cells display fluorescence intensities ranging between $\mathrm{G} 2 / \mathrm{M}$ and G0/G1 cells. Measurement of the incorporation rate of nucleoside-like probes (such as BrdU or ${ }^{3} \mathrm{H}$-thymidine) in DNA, which occurs during the $S$ phase of the cell cycle.

Measurement of the ability of cells to form clonic colonies on agar dishes. Individual cells able to proliferate form aggregates that can be fixed, stained and counted.

Phase contrast microscopy can be informative of cell death type (e.g., swelling during necrosis or shrinking during apoptosis).

Recording and assembling images obtained with phase contrast or fluorescence microscopy allows evaluation of proliferation rate and motility of adherent cells.

Microscopic observation of adherent cells can help determining cell detachment by means of cell density evaluation.

Detection (i) of externalized phosphatidylserine moieties, an early hallmark of apoptosis, by fluorescently labeled annexin V; and (ii) of membrane's integrity disruption, a marker of necrosis or late-stage apoptosis, by PI staining of DNA and RNA.

The measurement of the activity of caspase 3, a key enzyme of apoptotic processes, reflects the apoptosis rate. Measurement of autophagic vacuoles accumulation. Acridine orange penetrates cells freely and emits orangered fluorescence in acidic environments such as in lysosomes.

Lipophilic cationic fluorescent dyes, such as rhodamine 123 , are readily sequestered by the matrix of active mitochondria. When mitochondrial membrane potential drops, fluorescence no longer localizes in the mitochondria but in the whole cytoplasm.

The Comet assay is a single cell gel electrophoresis method that measures DNA strands breakage.

The TUNEL assay relies on the evaluation of DNA fragmentation, a feature of apoptosis. DNA breaks present nicks to which dUTP is added with help of the TdT enzyme. The addition of a fluorescent tag or specific antibodies allows the detection of dUTP, either by flow cytometry, fluorescence microscopy, or spectrophotometry. DSBs fragmentations can be quantified using serine139-phosphorylated histone $\mathrm{H} 2 \mathrm{AX}(\mathrm{H} 2 \mathrm{AX})$, a marker for DNA damages that can be detected with specific antibodies. Fluorescence microscopy allows for the determination of $\mathrm{yH} 2 \mathrm{AX}$ foci, a direct measurement of DSBs.

An auxotrophic bacterial strain is cultivated on a medium depleted in an essential amino acid. Genotoxic compounds able to induce mutations can reverse the auxotrophic characteristic, resulting in bacterial clones growth. Colonies can then be counted.

The nucleus of cells suffering DNA damages can exclude portions of chromosomes. Fixing and staining the cells with a DNA probe allows the detection of micronuclei under a microscope.

The assay is based on the measurement of ${ }^{3} \mathrm{H}$-thymidine incorporation in the DNA of cells that are not supposed to replicate their chromosomes (i.e., repair cells in the $\mathrm{S}$ phase).

Oxidative properties of ROS/RNS are used to convert more or less specific probes into fluorophores. These are quantified with a fluorometer or with a flow cytometer.

Among the most widely used methods, the reduction of TNB to DTNB allows indirect spectrophotometric determination of reduced glutathione.

Thiobarbituric acid reacts with aldehydes which are the end-products of lipid peroxidation. The generated product can be assessed fluorometrically or spectrophotometrically.

continued 
Table 2 Continued

\begin{tabular}{ll}
$\begin{array}{l}\text { Test } \\
\text { Other assays }\end{array}$ & Principle of the assay \\
Cytoskeleton integrity & $\begin{array}{l}\text { Methods notably include fluorescence immunostaining or phalloidin staining prior to microscopic examination } \\
\text { or flow cytometric determination. }\end{array}$ \\
\hline Reporter genes & $\begin{array}{l}\text { Upon activation of the investigated pathway, a transfected reporter (marker) gene is expressed; generally a } \\
\text { fluorescent protein. Fluorescence microscopy or flow cytometry can be used to detect or quantify the expression } \\
\text { of target genes. }\end{array}$ \\
\hline Toxicogenomics & $\begin{array}{l}\text { Toxicogenomics rely on an array of techniques that allow collecting exhaustive data related to the expression of } \\
\text { genes, proteins, and metabolites in order to assess the toxicological potential of a substance. }\end{array}$ \\
Model organisms & $\begin{array}{l}\text { These include in vivo organisms that are compatible with medium/high throughput experiments (e.g., zebrafish, } \\
\text { Caenorhabditis elegans, Drosophilia melanogaster). They provide higher degree of physiological relevance and } \\
\text { mechanistic information than in vitro models. } \\
\text { Computer-assisted methods including, rule-based expert systems, QSAR models, or 3D computational docking, } \\
\text { that either compare a given compound with known toxicants or measure docking abilities towards biological } \\
\text { targets. }\end{array}$
\end{tabular}

\section{References}

1 Cragg GM, Boyd MR, Cardellina II JH, Newman DJ, Snader KM, Cloud TG. Ethnobotany and drug discovery: the experience of the US National Cancer Institute. In: Chadwick DJ, Marsh J, editors. Ethnobotany and the search for new drugs. Chichester: Wiley; 1994: 178-196

2 Evans D, Evans W, Trease G. Pharmacognosy, 16th edition. Amsterdam: Saunders Ltd.; 2009

3 Nguyen AT, Duez P. Cytotoxic-anticancer drugs from medicinal plants. In: Matsumoto T, editor. Phytochemistry research progress. New York: Nova Science Publishers, Inc.; 2008: 193-208

4 Verpoorte R, Houghton PJ, Heinrich M, Mukherjee PK, Hirschmann GS, van Staden J, Yesilada E. Editorial. J Ethnopharmacol 2006; 103: 309310

5 Shaw D, Ladds G, Duez P, Williamson E, Chan K. Pharmacovigilance of herbal medicine. J Ethnopharmacol 2012; 140: 513-518

6 Zhang L, Yan J, Liu X, Ye Z, Yang X, Meyboom R, Chan K, Shaw D, Duez P. Pharmacovigilance practice and risk control of Traditional Chinese Medicine drugs in China: current status and future perspective. J Ethnopharmacol 2012; 140: 519-525

7 Biringanine G, Vray B, Vercruysse V, Vanhaelen-Fastre R, Vanhaelen M, Duez P. Polysaccharides extracted from the leaves of Plantago palmata Hook.f. induce nitric oxide and tumor necrosis factor-alpha production by interferon-gamma-activated macrophages. Nitr Oxide 2005; 12: 1-

8 Santos NC, Figueira-Coelho J, Martins-Silva J, Saldanha C. Multidisciplinary utilization of dimethyl sulfoxide: pharmacological, cellular, and molecular aspects. Biochem Pharmacol 2003; 65: 1035-1041

9 Ponzio G, Loubat A, Rochet N, Turchi L, Rezzonico R, Farahi Far D, Dulic V, Rossi B. Early G1 growth arrest of hybridoma B cells by DMSO involves cyclin D2 inhibition and p21[CIP1] induction. Oncogene 1998; 17: $1159-1166$

10 Julien C, Marcouiller F, Bretteville A, El Khoury NB, Baillargeon J, Hebert SS, Planel E. Dimethyl sulfoxide induces both direct and indirect tau hyperphosphorylation. PLoS One 2012; 7: e40020

11 David RM, Jones HS, Panter GH, Winter MJ, Hutchinson TH, Kevin Chipman J. Interference with xenobiotic metabolic activity by the commonly used vehicle solvents dimethylsulfoxide and methanol in zebrafish (Danio rerio) larvae but not Daphnia magna. Chemosphere 2012; 88: 912-917

12 Da Violante G, Zerrouk N, Richard I, Provot G, Chaumeil JC, Arnaud P. Evaluation of the cytotoxicity effect of dimethyl sulfoxide (DMSO) on Caco2/TC7 colon tumor cell cultures. Biol Pharm Bull 2002; 25: 16001603

13 Tice RR, Agurell E, Anderson D, Burlinson B, Hartmann A, Kobayashi H, Miyamae Y, Rojas E, Ryu JC, Sasaki YF. Single cell gel/comet assay: guidelines for in vitro and in vivo genetic toxicology testing. Environ Mol Mutagen 2000; 35: 206-221

14 Charles C, Chemais M, Stevigny C, Dubois J, Nachergael A, Duez P. Measurement of the influence of flavonoids on DNA repair kinetics using the comet assay. Food Chem 2012; 135: 2974-2981

15 Galluzzi L, Vitale I, Abrams JM, Alnemri ES, Baehrecke EH, Blagosklonny MV, Dawson TM, Dawson VL, El-Deiry WS, Fulda S, Gottlieb E, Green DR,
Hengartner MO, Kepp O, Knight RA, Kumar S, Lipton SA, Lu X, Madeo F, Malorni W, Mehlen P, Nunez G, Peter ME, Piacentini M, Rubinsztein DC, Shi Y, Simon HU, Vandenabeele P, White E, Yuan J, Zhivotovsky B, Melino $G$, Kroemer $G$. Molecular definitions of cell death subroutines: recommendations of the Nomenclature Committee on Cell Death 2012. Cell Death Differ 2012; 19: 107-120

16 Kroemer G, Galluzzi L, Vandenabeele P, Abrams J, Alnemri ES, Baehrecke EH, Blagosklonny MV, El-Deiry WS, Golstein P, Green DR, Hengartner M, Knight RA, Kumar S, Lipton SA, Malorni W, Nunez G, Peter ME, Tschopp J, Yuan J, Piacentini M, Zhivotovsky B, Melino G. Classification of cell death: recommendations of the Nomenclature Committee on Cell Death 2009. Cell Death Differ 2009; 16: 3-11

17 Majno G, Joris I. Apoptosis, oncosis, and necrosis. An overview of cell death. Am J Pathol 1995; 146: 3-15

18 Schwartzman RA, Cidlowski JA. Apoptosis: the biochemistry and molecular biology of programmed cell death. Endocr Rev 1993; 14: 133-151

19 Hotchkiss RS, Strasser A, McDunn JE, Swanson PE. Cell death. N Engl J Med 2009; 361: 1570-1583

20 Krysko DV, Vanden Berghe T, D'Herde K, Vandenabeele P. Apoptosis and necrosis: detection, discrimination and phagocytosis. Methods 2008; 44: 205-221

21 Proskuryakov SY, Konoplyannikov AG, Gabai VL. Necrosis: a specific form of programmed cell death? Exp Cell Res 2003; 283: 1-16

22 Zhivotovsky B. Apoptosis, necrosis and between. Cell Cycle 2004; 3: 6466

23 Elmore S. Apoptosis: a review of programmed cell death. Toxicol Pathol 2007; 35: 495-516

24 Ward TH, Cummings J, Dean E, Greystoke A, Hou JM, Backen A, Ranson M, Dive C. Biomarkers of apoptosis. Br J Cancer 2008; 99: 841-846

25 Kiechle FL, Zhang X. Apoptosis: biochemical aspects and clinical implications. Clin Chim Acta 2002; 326: 27-45

26 Shen HM, Codogno P. Autophagy is a survival force via suppression of necrotic cell death. Exp Cell Res 2012; 318: 1304-1308

27 Korsnes MS, Espenes A, Hetland DL, Hermansen LC. Paraptosis-like cell death induced by yessotoxin. Toxicol In Vitro 2011; 25: 1764-1770

28 Sperandio S, de Belle I, Bredesen DE. An alternative, nonapoptotic form of programmed cell death. Proc Natl Acad Sci USA 2000; 97: 1437614381

29 Sperandio S, Poksay K, de Belle I, Lafuente MJ, Liu B, Nasir J, Bredesen DE. Paraptosis: mediation by MAP kinases and inhibition by AIP-1/Alix. Cell Death Differ 2004; 11: 1066-1075

30 Yoon MJ, Kim EH, Kwon TK, Park SA, Choi KS. Simultaneous mitochondrial $\mathrm{Ca}(2+)$ overload and proteasomal inhibition are responsible for the induction of paraptosis in malignant breast cancer cells. Cancer Lett 2012; 324: 197-209

31 Fink SL, Cookson BT. Apoptosis, pyroptosis, and necrosis: mechanistic description of dead and dying eukaryotic cells. Infect Immun 2005; 73: 1907-1916

32 Slater TF, Sawyer B, Straeuli U. Studies on succinate-tetrazolium reductase systems. III. Points of coupling of four different tetrazolium salts. Biochim Biophys Acta 1963; 77: 383-393 
33 Mosmann T. Rapid colorimetric assay for cellular growth and survival: application to proliferation and cytotoxicity assays. J Immunol Methods $1983 ; 65$ : 55-63

34 Berridge MV, Tan AS. Characterization of the cellular reduction of 3(4,5-dimethylthiazol-2-yl)-2,5-diphenyltetrazolium bromide (MTT): subcellular localization, substrate dependence, and involvement of mitochondrial electron transport in MTT reduction. Arch Biochem Biophys 1993; 303: 474-482

35 Berridge MV, Herst PM, Tan AS. Tetrazolium dyes as tools in cell biology: new insights into their cellular reduction. Biotechnol Annu Rev 2005; 11: 127-152

36 Scudiero DA, Shoemaker RH, Paull KD, Monks A, Tierney S, Nofziger TH, Currens MJ, Seniff D, Boyd MR. Evaluation of a soluble tetrazolium/ formazan assay for cell growth and drug sensitivity in culture using human and other tumor cell lines. Cancer Res 1988; 48: 4827-4833

37 Goodwin CJ, Holt SJ, Downes S, Marshall NJ. Microculture tetrazolium assays: a comparison between two new tetrazolium salts, XTT and MTS. J Immunol Methods 1995; 179: 95-103

38 Shoemaker M, Cohen I, Campbell M. Reduction of MTT by aqueous herbal extracts in the absence of cells. J Ethnopharmacol 2004; 93: 381-384

39 Bruggisser R, von Daeniken K, Jundt G, Schaffner W, Tullberg-Reinert H. Interference of plant extracts, phytoestrogens and antioxidants with the MTT tetrazolium assay. Planta Med 2002; 68: 445-448

40 Wisman KN, Perkins AA, Jeffers MD, Hagerman AE. Accurate assessment of the bioactivities of redox-active polyphenolics in cell culture. J Agric Food Chem 2008; 56: 7831-7837

41 Wang $P$, Henning SM, Heber D. Limitations of MTT and MTS-based assays for measurement of antiproliferative activity of green tea polyphenols. PLoS One 2010; 5: e10202

42 Muraina IA, Suleiman MM, Eloff JN. Can MTT be used to quantify the antioxidant activity of plant extracts? Phytomedicine 2009; 16: 665668

43 Pagliacci MC, Spinozzi F, Migliorati G, Fumi G, Smacchia M, Grignani F, Riccardi C, Nicoletti I. Genistein inhibits tumour cell growth in vitro but enhances mitochondrial reduction of tetrazolium salts: a further pitfall in the use of the MTT assay for evaluating cell growth and survival. Eur J Cancer 1993; 29 A: 1573-1577

44 Naoi T, Shibuya N, Inoue H, Mita S, Kobayashi S, Watanabe K, Orino K. The effect of tert-butylhydroquinone-induced oxidative stress in MDBK cells using XTT assay: implication of tert-butylhydroquinoneinduced NADPH generating enzymes. J Vet Med Sci 2010; 72: 321-326

45 Hamid R, Rotshteyn Y, Rabadi L, Parikh R, Bullock P. Comparison of alamar blue and MTT assays for high through-put screening. Toxicol In Vitro 2004; 18: 703-710

46 Thorne N, Auld DS, Inglese J. Apparent activity in high-throughput screening: origins of compound-dependent assay interference. Curr Opin Chem Biol 2010; 14: 315-324

47 Yu HG, Chung H, Yu YS, Seo JM, Heo JW. A new rapid and non-radioactive assay for monitoring and determining the proliferation of retinal pigment epithelial cells. Korean J Ophthalmol 2003; 17: 29-34

48 Zhi-Jun Y, Sriranganathan N, Vaught T, Arastu SK, Ansar Ahmed S. A dyebased lymphocyte proliferation assay that permits multiple immunological analyses: mRNA, cytogenetic, apoptosis, and immunophenotyping studies. J Immunol Methods 1997; 210: 25-39

49 Erikstein BS, Hagland HR, Nikolaisen J, Kulawiec M, Singh KK, Gjertsen $B T$, Tronstad KJ. Cellular stress induced by resazurin leads to autophagy and cell death via production of reactive oxygen species and mitochondrial impairment. J Cell Biochem 2010; 111: 574-584

50 Goegan P, Johnson G, Vincent R. Effects of serum protein and colloid on the alamarBlue assay in cell cultures. Toxicol In Vitro 1995; 9: 257-266

51 Repetto G, del Peso A, Zurita JL. Neutral red uptake assay for the estimation of cell viability/cytotoxicity. Nat Protoc 2008; 3: 1125-1131

52 Borenfreund E, Puerner JA. Toxicity determined in vitro by morphological alterations and neutral red absorption. Toxicol Lett 1985; 24 : 119 124

53 Hall JO, Novakofski JE, Beasley VR. Neutral red assay modification to prevent cytotoxicity and improve reproducibility using E-63 rat skeletal muscle cells. Biotechnol Histochem 1998; 73: 211-221

54 Higashi T, Isomoto A, Tyuma I, Kakishita E, Uomoto M, Nagai K. Quantitative and continuous analysis of ATP release from blood platelets with firefly luciferase luminescence. Thromb Haemost 1985; 53: 65-69

55 Crouch SP, Kozlowski R, Slater KJ, Fletcher J. The use of ATP bioluminescence as a measure of cell proliferation and cytotoxicity. J Immunol Methods 1993; 160: 81-88
56 Squatrito RC, Connor JP, Buller RE. Comparison of a novel redox dye cell growth assay to the ATP bioluminescence assay. Gynecol Oncol 1995; 58: 101-105

57 Fan F, Wood KV. Bioluminescent assays for high-throughput screening. Assay Drug Dev Technol 2007; 5: 127-136

58 Ulukaya E, Ozdikicioglu F, Oral AY, Demirci M. The MTT assay yields a relatively lower result of growth inhibition than the ATP assay depending on the chemotherapeutic drugs tested. Toxicol In Vitro 2008; 22: 232-239

59 Thorne N, Inglese J, Auld DS. Illuminating insights into firefly luciferase and other bioluminescent reporters used in chemical biology. Chem Biol 2010; 17: 646-657

60 Bakhtiarova A, Taslimi P, Elliman SJ, Kosinski PA, Hubbard B, Kavana M, Kemp DM. Resveratrol inhibits firefly luciferase. Biochem Biophys Res Commun 2006; 351: 481-484

61 Leitao JM, Esteves da Silva JC. Firefly luciferase inhibition. J Photochem Photobiol B 2010; 101: 1-8

62 Shimomura Y, Kawada T, Suzuki M. Capsaicin and its analogs inhibit the activity of NADH-coenzyme Q oxidoreductase of the mitochondrial respiratory chain. Arch Biochem Biophys 1989; 270: 573-577

63 Cheng SC, Pardini RS. Structure-inhibition relationships of various phenolic compounds towards mitochondrial respiration. Pharmacol Res Commun 1978; 10: 897-910

64 Gledhill JR, Montgomery MG, Leslie AGW, Walker JE. Mechanism of inhibition of bovine F1-ATPase by resveratrol and related polyphenols. Proc Natl Acad Sci USA 2007; 104: 13632-13637

65 Chan GK, Kleinheinz TL, Peterson D, Moffat JG. A simple high-content cell cycle assay reveals frequent discrepancies between cell number and ATP and MTS proliferation assays. PLoS One 2013; 8: e63583

66 Kitami T, Logan DJ, Negri J, Hasaka T, Tolliday NJ, Carpenter AE, Spiegelman BM, Mootha VK. A chemical screen probing the relationship between mitochondrial content and cell size. PLoS One 2012; 7: e33755

67 Kluza J, Marchetti P, Gallego MA, Lancel S, Fournier C, Loyens A, Beauvillain JC, Bailly C. Mitochondrial proliferation during apoptosis induced by anticancer agents: effects of doxorubicin and mitoxantrone on cancer and cardiac cells. Oncogene 2004; 23: 7018-7030

68 Renner K, Amberger A, Konwalinka G, Kofler R, Gnaiger E. Changes of mitochondrial respiration, mitochondrial content and cell size after induction of apoptosis in leukemia cells. Biochim Biophys Acta 2003; 1642: 115-123

69 Abe K, Matsuki N. Measurement of cellular 3-(4,5-dimethylthiazol-2yl)-2,5-diphenyltetrazolium bromide (MTT) reduction activity and lactate dehydrogenase release using MTT. Neurosci Res 2000; 38: 325329

70 Korzeniewski C, Callewaert DM. An enzyme-release assay for natural cytotoxicity. J Immunol Methods 1983; 64: 313-320

71 Weyermann J, Lochmann D, Zimmer A. A practical note on the use of cytotoxicity assays. Int J Pharm 2005; 288: 369-376

72 Schofield P, Mbugua DM, Pell AN. Analysis of condensed tannins: a review. Anim Feed Sci Technol 2001; 91: 21-40

73 Bruneton J. Pharmacognosie:Phytochimie, Plantes médicinales, 4th edition. Paris: Lavoisier; 2009

74 Goldstein JL, Swain T. The inhibition of enzymes by tannins. Phytochemistry $1965 ; 4: 185-192$

75 Kendig DM, Tarloff JB. Inactivation of lactate dehydrogenase by several chemicals: implications for in vitro toxicology studies. Toxicol In Vitro 2007; 21: 125-132

76 Bottger S, Hofmann K, Melzig MF. Saponins can perturb biologic membranes and reduce the surface tension of aqueous solutions: a correlation? Bioorg Med Chem 2012; 20: 2822-2828

77 Grankvist K, Lernmark A, Taljedal IB. Alloxan cytotoxicity in vitro. Microscope photometric analyses of Trypan Blue uptake by pancreatic islet cells in suspension. Biochem J 1977; 162: 19-24

78 Uliasz TF, Hewett SJ. A microtiter trypan blue absorbance assay for the quantitative determination of excitotoxic neuronal injury in cell culture. J Neurosci Methods 2000; 100: 157-163

$79 \mathrm{Hu}$ J, el-Fakahany EE. An artifact associated with using trypan blue exclusion to measure effects of amyloid beta on neuron viability. Life Sci 1994; 55: 1009-1016

80 Johnson I, Spence M. The Molecular Probes ${ }^{\circledR}$ Handbook, 11th edition, Section 12.5. Available at http://www.lifetechnologies.com/be/en/ home/references/molecular-probes-the-handbook.html. Accessed December 11, 2013. 
81 Sonnenbichler J, Scalera F, Sonnenbichler I, Weyhenmeyer R. Stimulatory effects of silibinin and silicristin from the milk thistle Silybum marianum on kidney cells. J Pharmacol Exp Ther 1999; 290: 1375-1383

82 Nunez $R$. DNA measurement and cell cycle analysis by flow cytometry. Curr Issues Mol Biol 2001; 3: 67-70

83 Nicoletti I, Migliorati G, Pagliacci MC, Grignani F, Riccardi C. A rapid and simple method for measuring thymocyte apoptosis by propidium iodide staining and flow cytometry. J Immunol Methods 1991; 139: 271-279

84 Taupin P. BrdU immunohistochemistry for studying adult neurogenesis: paradigms, pitfalls, limitations, and validation. Brain Res Rev 2007; 53: 198-214

85 Munshi A, Hobbs M, Meyn R. Clonogenic cell survival assay. In: Blumenthal RD, editor. Methods in molecular medicine. Totawa: Humana Press; 2005: 21-28

86 Franken NA, Rodermond HM, Stap J, Haveman J, van Bree C. Clonogenic assay of cells in vitro. Nat Protoc 2006; 1: 2315-2319

87 Quto b SS, $\mathrm{Ng}$ CE. Comparison of apoptotic, necrotic and clonogenic cell death and inhibition of cell growth following camptothecin and X-radiation treatment in a human melanoma and a human fibroblast cell line. Cancer Chemother Pharmacol 2002; 49: 167-175

88 Saraste A. Morphologic criteria and detection of apoptosis. Herz 1999; 24: 189-195

89 Wang C, Jiang Z, Yao J, Wu X, Sun L, Liu C, Duan W, Yan M, Liu J, Zhang L. Participation of cathepsin B in emodin-induced apoptosis in HK-2 cells. Toxicol Lett 2008; 181: 196-204

90 Galluzzi L, Aaronson SA, Abrams J, Alnemri ES, Andrews DW, Baehrecke EH, Bazan NG, Blagosklonny MV, Blomgren K, Borner C, Bredesen DE, Brenner C, Castedo M, Cidlowski JA, Ciechanover A, Cohen GM, De Laurenzi $V$, De Maria $R$, Deshmukh $M$, Dynlacht $B D$, El-Deiry WS, Flavell $R A$, Fulda S, Garrido C, Golstein P, Gougeon ML, Green DR, Gronemeyer $H$, Hajnoczky G, Hardwick JM, Hengartner MO, Ichijo H, Jaattela M, Kepp O, Kimchi A, Klionsky DJ, Knight RA, Kornbluth S, Kumar S, Levine B, Lipton SA, Lugli E, Madeo F, Malomi W, Marine JC, Martin SJ, Medema JP, Mehlen P, Melino G, Moll UM, Morselli E, Nagata S, Nicholson DW, Nicotera P, Nunez G, Oren M, Penninger J, Pervaiz S, Peter ME, Piacentini M, Prehn JH, Puthalakath H, Rabinovich GA, Rizzuto R, Rodrigues CM, Rubinsztein DC, Rudel T, Scorrano L, Simon HU, Steller H, Tschopp J, Tsujimoto Y, Vandenabeele P, Vitale I, Vousden KH, Youle RJ, Yuan J, Zhivotovsky B, Kroemer G. Guidelines for the use and interpretation of assays for monitoring cell death in higher eukaryotes. Cell Death Differ 2009; 16: 1093-1107

91 Bury M, Novo-Uzal E, Andolfi A, Cimini S, Wauthoz N, Heffeter P, Lallemand B, Avolio F, Delporte C, Cimmino A, Dubois J, Van Antwerpen P, Zonno MC, Vurro M, Poumay Y, Berger W, Evidente A, De Gara L, Kiss R, Locato $V$. Ophiobolin A, a sesterterpenoid fungal phytotoxin, displays higher in vitro growth-inhibitory effects in mammalian than in plant cells and displays in vivo antitumor activity. Int J Oncol 2013; 43: 575-585

92 Nacoulma A. Reprogrammation métabolique induite dans les tissus hyperplasique formés chez le tabac infecté par Rodococcusfascians: aspects fondamentaux et applications potentielles [PhD Thesis]. Brussels: Université Libre de Bruxelles; 2013

93 Debeir O, Megalizzi V, Warzee N, Kiss R, Decaestecker C. Videomicroscopic extraction of specific information on cell proliferation and migration in vitro. Exp Cell Res 2008; 314: 2985-2998

$94 \mathrm{Hu}$ Q Noor M, Wong YF, Hylands PJ, Simmonds MS, Xu Q Jiang D, Hendry $B M$. In vitro anti-fibrotic activities of herbal compounds and herbs. Nephrol Dial Transplant 2009; 24: 3033-3041

95 Vermes I, Haanen C, Steffens-Nakken H, Reutelingsperger C. A novel assay for apoptosis. Flow cytometric detection of phosphatidylserine expression on early apoptotic cells using fluorescein labelled Annexin V. J Immunol Methods 1995; 184: 39-51

96 Verzola D, Gandolfo MT, Salvatore F, Villaggio B, Gianiorio F, Traverso P, Deferrari G, Garibotto $G$. Testosterone promotes apoptotic damage in human renal tubular cells. Kidney Int 2004; 65: 1252-1261

97 Jacob MC, Favre M, Bensa JC. Membrane cell permeabilization with saponin and multiparametric analysis by flow cytometry. Cytometry 1991; 12: 550-558

98 Wang C, Wu X, Chen M, Duan W, Sun L, Yan M, Zhang L. Emodin induces apoptosis through caspase 3-dependent pathway in HK-2 cells. Toxicology 2007; 231: 120-128

99 Fan C, Wang W, Zhao B, Zhang S, Miao J. Chloroquine inhibits cell growth and induces cell death in A549 lung cancer cells. Bioorg Med Chem 2006; 14: 3218-3222
$100 \mathrm{Li}$ B. Chaine respiratoire et pore de transition de permeabilité mitochondriale dans la cardioprotection [PhD Thesis]. Lyon: Université Claude Bernard; 2009

101 Zhu B, Zhai Q Yu B. Tanshinone IIA protects rat primary hepatocytes against carbon tetrachloride toxicity via inhibiting mitochondria permeability transition. Pharm Biol 2010; 48: 484-487

102 Baumann S, Fas SC, Giaisi M, Muller WW, Merling A, Gulow K, Edler L, Krammer PH, Li-Weber M. Wogonin preferentially kills malignant lymphocytes and suppresses T-cell tumor growth by inducing PLCgamma1- and Ca2+-dependent apoptosis. Blood 2008; 111: 2354-2363

103 Singh NP, McCoy MT, Tice RR, Schneider EL. A simple technique for quantitation of low levels of DNA damage in individual cells. Exp Cell Res 1988; 175: 184-191

104 Fairbairn DW, Olive PL, O'Neill KL. The comet assay: a comprehensive review. Mutat Res 1995; 339: 37-59

105 Anderson D, Yu TW, McGregor DB. Comet assay responses as indicators of carcinogen exposure. Mutagenesis 1998; 13: 539-555

106 Rojas E, Lopez MC, Valverde M. Single cell gel electrophoresis assay: methodology and applications. J Chromatogr B Biomed Sci Appl 1999; 722: 225-254

107 Hartmann A, Speit G. The contribution of cytotoxicity to DNA-effects in the single cell gel test (comet assay). Toxicol Lett 1997; 90: 183-188

108 Horvathova E, Dusinska M, Shaposhnikov S, Collins AR. DNA damage and repair measured in different genomic regions using the comet assay with fluorescent in situ hybridization. Mutagenesis 2004; 19: 269-276

109 Gedik CM, Ewen SW, Collins AR. Single-cell gel electrophoresis applied to the analysis of UV-C damage and its repair in human cells. Int J Radiat Biol 1992; 62: 313-320

110 Olive PL. DNA damage and repair in individual cells: applications of the comet assay in radiobiology. Int J Radiat Biol 1999; 75: 395-405

111 Bocker W, Bauch T, Muller WU, Streffer C. Image analysis of comet assay measurements. Int J Radiat Biol 1997; 72: 449-460

112 Olive PL, Banath JP, Durand RE. Heterogeneity in radiation induced DNA damage and repair in tumor and normal cells measured using the 'comet' assay. Radiat Res 1990; 122: 86-94

113 Speit G, Vasquez M, Hartmann A. The comet assay as an indicator test for germ cell genotoxicity. Mutat Res 2009; 681: 3-12

114 Berthelot-Ricou A, Perrin J, Di Giorgio C, De Meo M, Botta A, Courbiere B. Comet assay on mouse oocytes: an improved technique to evaluate genotoxic risk on female germ cells. Fertil Steril 2011; 95: 1452-1457

115 Duez P, Dehon G, Kumps A, Dubois J. Statistics of the Comet assay: a key to discriminate between genotoxic effects. Mutagenesis 2003; 18: 159-166

116 Speit G, Brendler-Schwaab S, Hartmann A, Pfuhler S. The in vivo comet assay: use and status in genotoxicity testing. Mutagenesis 2005; 20: 245-254

117 Kim YJ, Park HJ, Yoon SH, Kim MJ, Leem KH, Chung JH, Kim HK. Anticancer effects of oligomeric proanthocyanidins on human colorectal cancer cell line, SNU-C4. World J Gastroenterol 2005; 11: 4674-4678

118 Martins C, Doran C, Laires A, Rueff J, Rodrigues AS. Genotoxic and apoptotic activities of the food flavourings myristicin and eugenol in AA8 and XRCC1 deficient EM9 cells. Food Chem Toxicol 2011; 49: 385-392

119 Heatwole VM. TUNEL assay for apoptotic cells. Methods Mol Biol 1999; 115: 141-148

120 Stahelin BJ, Marti U, Solioz M, Zimmermann H, Reichen J. False positive staining in the TUNEL assay to detect apoptosis in liver and intestine is caused by endogenous nucleases and inhibited by diethyl pyrocarbonate. Mol Pathol 1998; 51: 204-208

121 Bonner WM, Redon CE, Dickey JS, Nakamura AJ, Sedelnikova OA, Solier S, Pommier Y. GammaH2AX and cancer. Nat Rev Cancer 2008; 8: 957967

122 Muslimovic A, Ismail IH, Gao Y, Hammarsten O. An optimized method for measurement of gamma-H2AX in blood mononuclear and cultured cells. Nat Protoc 2008; 3: 1187-1193

123 Smart DJ, Ahmedi KP, Harvey JS, Lynch AM. Genotoxicity screening via the gammaH2AX by flow assay. Mutat Res 2011; 715: 25-31

124 Verschaeve L, Juutilainen J, Lagroye I, Miyakoshi J, Saunders R, de Seze R, Tenforde T, van Rongen E, Veyret $B, X u Z$. In vitro and in vivo genotoxicity of radiofrequency fields. Mutat Res 2010; 705: 252-268

125 Sedelnikova OA, Rogakou EP, Panyutin IG, Bonner WM. Quantitative detection of (125)IdU-induced DNA double-strand breaks with gammaH2AX antibody. Radiat Res 2002; 158: 486-492 
126 Bouquet F, Muller C, Salles B. The loss of gamma H2AX signal is a marker of DNA double strand breaks repair only a low levels of DNA damage. Cell Cycle 2006; 5: 1116-1122

127 Maron DM, Ames BN. Revised methods for the Salmonella mutagenicity test. Mutat Res 1983; 113: 173-215

128 Ramos A, Edreira A, Vizoso A, Betancourt J, Lopez M, Decalo M. Genotoxicity of an extract of Calendula officinalis L. J Ethnopharmacol 1998; 61: 49-55

129 Zhang H, Cifone MA, Murli H, Erexson GL, Mecchi MS, Lawlor TE. Application of simplified in vitro screening tests to detect genotoxicity of aristolochic acid. Food Chem Toxicol 2004; 42: 2021-2028

130 Ogura R, Ikeda N, Yuki K, Morita O, Saigo K, Blackstock C, Nishiyama N, Kasamatsu T. Genotoxicity studies on green tea catechin. Food Chem Toxicol 2008; 46: 2190-2200

131 EMEA. Overview of comments received on draft 'guideline on the assessment of genotoxic constituents in herbal Substances/preparations' (emea/hmpc/107079/2007). Available at: http://www.ema. europa.eu/docs/en_GB/document_library/Other/2009/09/ WC500003570.pdf. Accessed August 2013.

132 Bolognesi $C$. Genotoxicity of pesticides: a review of human biomonitoring studies. Mutat Res 2003; 543: 251-272

133 Fenech $M$. The in vitro micronucleus technique. Mutat Res 2000; 455: 81-95

134 Kirsch-Volders M, Sofuni T, Aardema M, Albertini S, Eastmond D, Fenech M, Ishidate jr. M, Kirchner S, Lorge E, Morita T, Norppa H, Surralles J, Vanhauwaert $A$, Wakata A. Report from the in vitro micronucleus assay working group. Mutat Res 2003; 540: 153-163

135 OECD. OECD guideline for the testing of chemicals: mammalian erythrocyte micronucleus test. Chemical safety and biosafety 1997; Testing of chemicals. Available at http://www.oecd.org/chemicalsafety/ testing/oecdguidelinesforthetestingofchemicals.htm. Accessed December 11, 2013.

136 Westerink WM, Schirris TJ, Horbach GJ, Schoonen WG. Development and validation of a high-content screening in vitro micronucleus assay in CHO-k1 and HepG2 cells. Mutat Res 2011; 724: 7-21

137 Lambert IB, Singer TM, Boucher SE, Douglas GR. Detailed review of transgenic rodent mutation assays. Mutat Res 2005; 590: 1-280

138 Bakkali F, Averbeck S, Averbeck D, Idaomar M. Biological effects of essential oils - a review. Food Chem Toxicol 2008; 46: 446-475

139 Droge $W$. Free radicals in the physiological control of cell function. Physiol Rev 2002; 82: 47-95

140 Zhao BL, Li XJ, He RG, Cheng SJ, Xin WJ. Scavenging effect of extracts of green tea and natural antioxidants on active oxygen radicals. Cell Biophys 1989; 14: 175-185

141 Abenavoli L, Capasso R, Milic N, Capasso F. Milk thistle in liver diseases: past, present, future. Phytother Res 2010; 24: 1423-1432

142 Paya M, Halliwell B, Hoult JR. Interactions of a series of coumarins with reactive oxygen species. Scavenging of superoxide, hypochlorous acid and hydroxyl radicals. Biochem Pharmacol 1992; 44: 205-214

143 Carr A, Frei B. Does vitamin C act as a pro-oxidant under physiological conditions? FASEB J 1999; 13: 1007-1024

144 Lapidot T, Walker MD, Kanner J. Can apple antioxidants inhibit tumor cell proliferation? Generation of $\mathrm{H}(2) \mathrm{O}(2)$ during interaction of phenolic compounds with cell culture media. J Agric Food Chem 2002; 50: 3156-3160

145 O'Brien PJ. Molecular mechanisms of quinone cytotoxicity. Chem Biol Interact 1991; 80: 1-41

146 Brisson M, Nguyen T, Wipf P, Joo B, Day BW, Skoko JS, Schreiber EM, Foster C, Bansal P, Lazo JS. Redox regulation of Cdc25B by cell-active quinolinediones. Mol Pharmacol 2005; 68: 1810-1820

147 Vasquez DR, Verrax J, Valderrama JA, Calderon PB. Aminopyrimidoisoquinolinequinone (APIQ) redox cycling is potentiated by ascorbate and induces oxidative stress leading to necrotic-like cancer cell death. Invest New Drugs 2012; 30: 1003-1011

148 Gomes A, Fernandes E, Lima JL. Fluorescence probes used for detection of reactive oxygen species. J Biochem Biophys Methods 2005; 65: 4580

149 Eruslanov E, Kusmartsev S. Identification of ROS using oxidized DCFDA and flow-cytometry. Methods Mol Biol 2010; 594: 57-72

150 Wardman P. Fluorescent and luminescent probes for measurement of oxidative and nitrosative species in cells and tissues: progress, pitfalls, and prospects. Free Radic Biol Med 2007; 43: 995-1022

151 Saengkhae C, Loetchutinat C, Garnier-Suillerot A. Kinetic analysis of fluorescein and dihydrofluorescein effluxes in tumour cells express- ing the multidrug resistance protein, MRP1. Biochem Pharmacol 2003; 65: 969-977

152 Hempel SL, Buettner GR, O'Malley YQ, Wessels DA, Flaherty DM. Dihydrofluorescein diacetate is superior for detecting intracellular oxidants: comparison with $2{ }^{\prime}, 7^{\prime}$-dichlorodihydrofluorescein diacetate, 5 (and 6)-carboxy-2',7'-dichlorodihydrofluorescein diacetate, and dihydrorhodamine 123. Free Radic Biol Med 1999; 27: 146-159

153 Pompella A, Visvikis A, Paolicchi A, De Tata V, Casini AF. The changing faces of glutathione, a cellular protagonist. Biochem Pharmacol 2003; 66: 1499-1503

154 Baker MA, Cerniglia GJ, Zaman A. Microtiter plate assay for the measurement of glutathione and glutathione disulfide in large numbers of biological samples. Anal Biochem 1990; 190: 360-365

155 Gallwitz H, Bonse S, Martinez-Cruz A, Schlichting I, Schumacher K, Krauth-Siegel RL. Ajoene is an inhibitor and subversive substrate of human glutathione reductase and Trypanosoma cruzi trypanothione reductase: crystallographic, kinetic, and spectroscopic studies. J Med Chem 1999; 42: 364-372

156 Rice GC, Bump EA, Shrieve DC, Lee W, Kovacs M. Quantitative analysis of cellular glutathione by flow cytometry utilizing monochlorobimane: some applications to radiation and drug resistance in vitro and in vivo. Cancer Res 1986; 46: 6105-6110

157 Kim DP, Yahav J, Sperandeo M, Maloney L, McTigue M, Lin F, Clark RA High cell density attenuates reactive oxygen species: implications for in vitro assays. Wound Repair Regen 2012; 20: 74-82

158 Patton S, Kurtz GW. 2-Thiobarbituric acid as a reagent for detecting milk fat oxidation. J Dairy Sci 1951; 34: 669-674

159 Guillen-Sans R, Guzman-Chozas M. The thiobarbituric acid (TBA) reaction in foods: a review. Crit Rev Food Sci Nutr 1998; 38: 315-330

160 Lefevre G, Beljean-Leymarie M, Beyerle F, Bonnefont-Rousselot D, Cristo $J P$, Therond $P$, Torreilles J. [Evaluation of lipid peroxidation by measuring thiobarbituric acid reactive substances]. Ann Biol Clin (Paris) 1998; 56: 305-319

161 Louzao MC, Ares IR, Cagide E, Espina B, Vilarino N, Alfonso A, Vieytes $M R$, Botana LM. Palytoxins and cytoskeleton: An overview. Toxicon 2011; 57: 460-469

162 Peterson JR, Mitchison TJ. Small molecules, big impact: a history of chemical inhibitors and the cytoskeleton. Chem Biol 2002; 9: 12751285

163 Borisy GG, Taylor EW. The mechanism of action of colchicine. Binding of colchincine-3H to cellular protein. J Cell Biol 1967; 34: 525-533

164 Nicolaou KC, Finlay MR, Ninkovic S, King NP, He Y, Li T, Sarabia F, Vourloumis D. Synthesis and biological properties of C12, 13-cyclopropylepothilone A and related epothilones. Chem Biol 1998; 5: 365-372

165 Small J, Rottner K, Hahne P, Anderson KI. Visualising the actin cytoskeleton. Microsc Res Tech 1999; 47: 3-17

166 Hayot C, Debeir O, Van Ham P, Van Damme M, Kiss R, Decaestecker C. Characterization of the activities of actin-affecting drugs on tumor cell migration. Toxicol Appl Pharmacol 2006; 211: 30-40

167 Simmons SO, Fan CY, Ramabhadran $R$. Cellular stress response pathway system as a sentinel ensemble in toxicological screening. Toxicol Sci 2009; 111: 202-225

168 Tsien RY. The green fluorescent protein. Annu Rev Biochem 1998; 67: 509-544

169 Crawford $A D$, Esguerra CV, de Witte PA. Fishing for drugs from nature: zebrafish as a technology platform for natural product discovery. Planta Med 2008; 74: 624-632

170 Borner FU, Schutz H, Wiedemann P. The fragility of omics risk and benefit perceptions. Toxicol Lett 2011; 201: 249-257

171 Bishop WE, Clarke DP, Travis CC. The genomic revolution: what does it mean for risk assessment? Risk Anal 2001; 21: 983-987

172 Heijne WH, Kienhuis AS, van Ommen B, Stierum RH, Groten JP. Systems toxicology: applications of toxicogenomics, transcriptomics, proteomics and metabolomics in toxicology. Expert Rev Proteomics 2005; 2: 767-780

173 Aardema MJ, MacGregor JT. Toxicology and genetic toxicology in the new era of "toxicogenomics": impact of "-omics" technologies. Mutat Res 2002; 499: 13-25

174 Marchant GE. Toxicogenomics and toxic torts. Trends Biotechnol 2002; 20: 329-332

175 Marques A, Lourenço HM, Nunes ML, Roseiro C, Santos C, Barranco A, Rainieri S, Langerholc T, Cencic A. New tools to assess toxicity, bioaccessibility and uptake of chemical contaminants in meat and seafood. Food Res Int 2011; 44: 510-522 
176 Lay jr. JO, Borgmann S, Liyanage R, Wilkins CL. Problems with the "omics". Trends Anal Chem 2006; 25: 1046-1056

177 Searfoss GH, Ryan TP, Jolly RA. The role of transcriptome analysis in pre-clinical toxicology. Curr Mol Med 2005; 5: 53-64

178 Ouedraogo M, Baudoux T, Stevigny C, Nortier J, Colet JM, Efferth T, Qu F, Zhou J, Chan K, Shaw D, Pelkonen O, Duez P. Review of current and "omics" methods for assessing the toxicity (genotoxicity, teratogenicity and nephrotoxicity) of herbal medicines and mushrooms. J Ethnopharmacol 2012; 140: 492-512

179 Selderslaghs IW, Blust R, Witters HE. Feasibility study of the zebrafish assay as an alternative method to screen for developmental toxicity and embryotoxicity using a training set of 27 compounds. Reprod Toxicol 2012; 33: 142-154

180 Blechinger SR, Warren jr. JT, Kuwada JY, Krone PH. Developmental toxicology of cadmium in living embryos of a stable transgenic zebrafish line. Environ Health Perspect 2002; 110: 1041-1046
181 Van Raamsdonk JM, Hekimi S. Reactive oxygen species and aging in Caenorhabditis elegans: causal or casual relationship? Antioxid Redox Signal 2010; 13: 1911-1953

182 Brenner S. The genetics of Caenorhabditis elegans. Genetics 1974; 77: 71-94

183 Leung MC, Williams PL, Benedetto A, Au C, Helmcke KJ, Aschner M, Meyer JN. Caenorhabditis elegans: an emerging model in biomedical and environmental toxicology. Toxicol Sci 2008; 106: 5-28

184 Gnoula C, Guissou I, Dubois J, Duez P. 5(6)-Carboxyfluorescein diacetate as an indicator of Caenorhabditis elegans viability for the development of an in vitro anthelmintic drug assay. Talanta 2007; 71: 18861892

185 Valerio jr. LG. In silico toxicology for the pharmaceutical sciences. Toxicol Appl Pharmacol 2009; 241: 356-370 